\title{
Mitos da "globalização"
}

\section{PAULO NOGUEIRA BATISTA JR.}

\section{Introdução}

$\mathrm{N}$ O BRASIL DOS ANOS 90, o tema da "globalização" vem marcando o debate sobre a economia mundial e as relações internacionais do país. Virou uma mania nacional. Reproduzindo, como sempre com algum atraso, as discussões iniciadas nos países desenvolvidos, especialmente nos EUA, os meios de comunicação de massa e diferentes setores da intelectualidade lançaram-se avidamente na discussão do assunto. O interesse acentuou-se depois que a abertura da economia e o programa de estabilização monetária iniciado em 1994 expuseram grande parte da economia, de modo abrupto, à competição internacional.

Infelizmente, não se pode dizer que a qualidade da discussão seja comparável à sua intensidade. $\mathrm{O}$ debate tem resvalado freqüentemente para a simplificação e a vulgaridade. A análise do quadro mundial é substituída pela propagação de slogans e chavões de diversos tipos. Predominam reações emocionais e reflexos atávicos, reveladores - quem sabe? - da natureza dos processos e problemas encobertos pela retórica da "globalização". A simples palavra parece ter algo de mágico. Na América Latina de um modo geral, e no Brasil em particular, a atitude em face da "globalização" oscila entre o medo e o fascínio, o pânico e o encantamento. Lembra a postura dos astecas de Montezuma diante dos espanhóis de Cortés.

Difundiu-se a percepção de que há processos em curso que dominam de maneira inexorável a economia mundial e tendem a destruir as fronteiras nacionais. Os Estados nacionais estariam em crise ou declínio irreversível. Em fase de extinção, segundo as versões mais extremadas.

Assim entendida, a "globalização" é um mito. Um fenômeno ideológico nem sempre muito sofisticado, que serve a propósitos variados. No plano editorial, por exemplo, ajuda a vender jornais, revistas e livros superficiais. Nos planos econômico e político, contribui para apanhar países ingênuos e despreparados na malha dos interesses internacionais dominantes.

Não há dúvida de que, como toda ideologia de sucesso, a ideologia da "globalização" tem um substrato de realidade, alguma conexão com os fatos que the confere certa plausibilidade. Apóia-se em meias-verdades. E, como disse um poeta inglês, Alfred Tennyson, "a mentira que é meia verdade é a pior das mentiras" (1).

1 Citado em Pessoa, 1994, p. 142. 
A ninguém escapa a extraordinária velocidade do progresso técnico em áreas como informática, telecomunicações e finanças. Essas inovações tecnológicas, associadas à diminuição dos custos de transporte, à desregulamentação de diversos mercados e à remoção de controles e barreiras, têm facilitado a crescente integração comercial e financeira dos mercados nacionais e a internacionalização dos próprios processos de produção em muitos setores (2). Nas últimas décadas, o comércio internacional vem crescendo quase sempre mais do que a produção mundial (3). Os investimentos diretos, mais do que o comércio (4). Ainda maior tem sido a expansão dos fluxos financeiros, muitas vezes de caráter volátil. Nos mercados de câmbio, o giro diário já supera o estoque de liquidez internacional à disposição dos bancos centrais dos países desenvolvidos.

É preciso, contudo, resguardar-se contra a carga de fantasia e mitologia construída a partir desses fenômenos reais. Há uma tendência bastante generalizada a exagerar o alcance dos fatos que servem de base à retórica da "globalização". Como veremos, o próprio termo é enganoso e só deveria ser utilizado entre aspas, para marcar distanciamento e ironia. O processo de internacionalização em curso nas últimas décadas não é nem tão abrangente e nem tão novo quanto sugerem os arautos da "globalização". Também não tem o caráter inexorável e irreversível que se lhe atribui com tanta freqüência.

Um exame cuidadoso da evolução da economia internacional não tardará a revelar o quanto são distorcidas as alegações da ideologia da "globalização", especialmente quando estabelece uma vinculação mecânica entre o avanço tecnológico, em áreas como informação, computação e finanças, e a suposta tendência geral à supressão das fronteiras e à desintegração dos Estados nacionais.

A rápida difusão dessas versões, que encontraram solo fértil no Brasil nos últimos anos, tornou mais importante uma avaliação crítica da evolução recente do quadro internacional. Um dos efeitos práticos da mitologia da "globalização", em especial da idéia de que estamos submetidos à ação de forças econômicas globais

2 Entre 1930 e 1990, o custo de uma chamada telefônica de três minutos entre Nova York e Londres, a preços de 1990, caiu de US\$244,65 para US\$ 3,32. No mesmo período, a receita média de transporte aéreo por milha de passageiro, também a preços de 1990, diminuiu de US\$ 0,68 para US\$ 0,11. O deflator de preços de computador, calculado pelo Departamento de Comércio do governo dos EUA, caiu de 125.000 em 1960 para 1.000 em 1990. International Monetary Fund, 1997b, p. 46.

3 Estima-se que a participação das exportações mundiais no PIB mundial tenha aumentado de cerca de 6\% em 1950 para 12\% em 1973 e 16\% em 1992. Nayyar, 1995, p. 3. Segundo dados do Fundo Monetário Internacional, o comércio mundial continuou crescendo mais do que o produto mundial nos anos recentes. Entre 1993 e 1996, o volume de comércio aumentou a uma taxa média de 7\% ao ano, contra um crescimento real médio de 3,6\% a.a. do PIB mundial. International Monetary Fund, 1997b, Apêndice Estatístico, tabelas A 1, A 22, p. 131, 159.

4 United Nations Conference on Trade and Developmente, 1996, p. 3, 5. Ver, também, Wade, 1996, p. 63. 
incontroláveis, é paralisar as iniciativas nacionais, que passam a ser rotuladas como ineficazes, sem maior discussão. A mensagem central é que as políticas nacionais têm de se curvar aos imperativos da "nova economia global". Qualquer desvio em relação aos supostos consensos da "globalização" é imediatamente tachado como inviável em face do julgamento e das sanções dos mercados internacionais, vistos como todopoderosos (Hirst \& Thompson, 1996:1).

Estabeleceu-se, assim, uma versão simplificada, porém intimidadora, das tendências econômicas internacionais. Essas mistificações servem, em primeira instância, aos propósitos dos setores e nações que se situam no comando do processo de internacionalização. Têm o propósito, ou pelo menos o efeito, de desarmar as iniciativas nacionais e remover as resistências sociais e políticas aos interesses econômico-financeiros que operam em escala internacional (5).

Do ponto de vista de certo tipo de governo, a ideologia da "globalização" pode ser de grande utilidade. É uma linha de argumentação que desfruta da eterna popularidade das explicações que economizam esforço de reflexão. Serve, muitas vezes, de cortina de fumaça. "Globalização" vira uma espécie de desculpa para tudo, uma explicação fácil para o que acontece de negativo no país. Governos fracos e omissos servem-se dessa retórica para isentar-se de responsabilidade, transferindo-a para um fenômeno impessoal e vago, fora do controle nacional. A ampla divulgação de avaliações superficiais das tendências internacionais acaba contribuindo para obstruir o debate sobre a política econômica e social e para dificultar a identificação dos erros das autoridades governamentais $(6)$.

É o que vem ocorrendo no Brasil no passado recente. Problemas provocados por decisões ou omissões do governo nacional têm sido sumariamente descarregados em cima da "globalização".

Por exemplo, se aumentam as taxas de desemprego, não falta quem se apresse a atribuir o problema à "globalização" e a caracterizá-lo como fenômeno mundial, que escapa em grande medida às possibilidades de atuação do governo. Se conglomerados estrangeiros absorvem empresas nacionais, inclusive firmas consideradas exemplares, como a Metal Leve do setor de autopeças, a explicação é imediata: são os efeitos inexoráveis da competição em escala global. Se o Brasil se tornou mais

5 Como observa Michel Rogalski, a "mundialização" é invocada para facilitar a aplicação de políticas de ajustamento cuja função consiste, no essencial, em ajustar o interno ao externo. Trata-se, assim, de favorecer no interior do país os interesses daqueles que são mais ligados ao exterior. Em nome da "mundialização", adotam-se políticas públicas que beneficiam as elites "modernas" e "competitivas", em detrimento muitas vezes da maior parte da população. Rogalski, 1997, p. 8-9.

6 Para Ignacy Sachs, os exageros quanto à influência da "mundialização" sobre a economia dos diferentes países são intencionais. Muitos governos, observa, ficam contentes de poder justificar tanto medidas impopulares, quanto a ausência de resultados das políticas adotadas, invocando uma força maior à qual estariam supostamente obrigados a se submeter. Sachs, 1997, p. 23-24. 
vulnerável do ponto de vista financeiro externo nos últimos três anos, esse é o preço inevitável que temos de pagar para aproveitar as inéditas oportunidades propiciadas pela "globalização financeira". Enfim, é um vale-tudo, que acaba tornando o debate pouco esclarecedor, para dizer o mínimo. A insistência com que se recorre, nesse contexto, à suposta inevitabilidade dos processos em andamento faz lembrar a observação do historiador inglês, A.J.P. Taylor, para quem "inevitabilidade" era "uma palavra mágica utilizada para mesmerizar os incautos” (Taylor, 1996:187).

A que atribuir o súbito interesse pelo tema da "globalização" no Brasil nos anos recentes? Nesse período, nada aconteceu na economia mundial que pudesse justificar a preocupação obsessiva com o tema. O que houve, na verdade, foi uma drástica mudança de rumo da política econômica brasileira desde o governo Collor, e sobretudo a partir de 1994 com o Plano Real, quando em nome da estabilização monetária o governo brasileiro adotou - em geral, sem a necessária preparação -, um conjunto de políticas nos campos cambial, financeiro e comercial, que submeteram a economia nacional de forma repentina à competição internacional.

Formou-se um quadro macroeconômico, caracterizado por forte e persistente valorização cambial, elevadas taxas de juro internas e rápida abertura às importações, que obrigou os produtores brasileiros a enfrentar, em condições desiguais, intensa competição externa. Não como resultado de um movimento impessoal e global, que ninguém controla, mas de políticas específicas seguidas pelo governo brasileiro.

Essas políticas macroeconômicas, associadas a distorções do sistema tributário brasileiro e a deficiências da infra-estrutura econômica, acabaram se revelando destrutivas para muitas empresas nacionais, especialmente as de menor porte e as mais expostas à competição com produtores estrangeiros. Ao mesmo tempo, a economia adquiriu uma propensão ao desequilíbrio externo; ficou mais dependente de capitais externos e mais vulnerável às flutuações do contexto financeiro internacional. Toda vez que a economia ganha impulso, com repercussões favoráveis sobre o mercado de trabalho, o déficit comercial e o déficit de balanço de pagamentos em conta corrente aumentam de forma alarmante.

Todas esses problemas têm pouco ou nada a ver com a famosa "globalização". Refletem, fundamentalmente, opções e omissões da política econômica nacional. Essas opções e omissões permitiram que se cristalizasse uma situação em que não se consegue encontrar uma combinação satisfatória de resultados nas contas externas e taxas de crescimento econômico. A taxa de crescimento que é satisfatória do ponto de vista do equilíbrio externo, é insuficiente do ponto de vista do equilíbrio interno, da prosperidade das empresas nacionais e da geração de empregos. A taxa de crescimento que é satisfatória do ponto de vista da produção e do emprego, acaba se revelando perigosa para as contas externas (7).

7 Sobre a evolução recente do quadro macroeconômico brasileiro, que não será objeto de discussão neste trabalho, ver Batista Jr., 1996, passim. 
Em suma, problemas como o desemprego e o subemprego, a desnacionalização da economia e a dependência de capitais externos, longe de constituírem a conseqüência irrecorrível de um processo global, resultam essencialmente de políticas adotadas no âmbito nacional, convenientemente dissimuladas pelo apelo à retórica da "globalização".

\section{Falsas novidades da "globalização"}

Convém deixar claro, antes de mais nada, que a "globalização" é, sob diversos pontos de vista, uma falsa novidade. Nas últimas décadas, com a hegemonia do tipo de abordagem que prevalece nos departamentos de economia das universidades dos EUA, o pensamento econômico distanciou-se da perspectiva histórica. Criou-se um ambiente intelectual propício para conferir ares de novidade a acontecimentos e tendências que constituem a repetição, sob nova roupagem, de fenômenos às vezes bastante antigos.

De um ponto de vista histórico, "globalização" é a palavra da moda para um processo que remonta, em última análise, à expansão da civilização européia a partir do final do século XV (Fernandes, 1996:32-34). Como lembra o historiador Marc Ferro, esse antigo processo de internacionalização e de criação de um mercado de alcance mundial foi lançado pela colonização, tendo resultado em ampliação das desigualdades entre os países colonizadores e os demais (Ferro, 1996:395). Caberia até indagar se a chamada "globalização" não seria a continuação da colonização por outros meios. E se o entusiasmo que suscita em muitos círculos, não só no Brasil, como em outros países da periferia subdesenvolvida, não seria um reflexo atávico da mentalidade colonial.

Seja como for, parece inegável que o grau de internacionalização econômica observado nas últimas duas ou três décadas tem precedentes históricos. Muitos dos fenômenos aduzidos para sugerir o advento de uma nova era constituem, na realidade, a retomada de processos e tendências bastante antigos.

Nesse contexto, vale a pena recordar, ainda que brevemente, alguns aspectos do quadro internacional que prevaleceu nas décadas anteriores à Primeira Guerra Mundial. Naquele período, ocorreu uma revolução tecnológica em transportes e comunicações, que favoreceu forte expansão dos fluxos internacionais (Nayyar, 1995: 10). Na realidade, a integração dos mercados mundiais, inclusive no que diz respeito à formação diária de preços, remonta à segunda metade do século XIX (Hirst \& Thompson, 1996: 9). Entre 1870 e a Primeira Guerra, vigorou um sistema econômico aberto, apoiado em comunicações eficientes de longa distância (cabos submarinos telegráficos intercontinentais) e em meios de transporte industrializados (navios a vapor e ferrovias). A proliferação das ferrovias e dos navios a vapor levou a uma grande redução dos custos de transporte (8).

8 International Monetary Fund, 1997b, p. 112-113. Nesse período, ocorreu também acentuada convergência dos preços das commodities entre países. Id., p. 113. 
É verdade que os métodos modernos de comunicação e transporte ampliaram dramaticamente o volume e a complexidade das transações, mas não se deve perder de vista que a economia internacional dispõe, há mais de 100 anos, de meios de informação e transporte capazes de sustentar um sistema genuinamente internacional. Como notam Hirst e Thompson, "if the theorists of globalization mean that we have an economy in which each part of the world is linked by markets sharing close to real-time information, then that began not in the 1970s but in the 1870s" (9).

Em Conseqüênciaseconômicas da paz, livro publicado em 1919, Keynes ofereceu uma descrição do sistema internacional da belle époque. Considere-se, por exemplo, a seguinte passagem: "What an extraordinary episode in the economic progress of man that age was which came to an end in August 1914! (...)The inhabitant of London could order by telephone, sipping his morning tea in bed, the various products of the whole earth, in such quantity as he might see fit, and reasonably expect their early delivery upon his doorstep; he could at same moment and by the same means adventure his wealth in the natural resources and new enterprises of any quarter of the world, and share, without exertion or even trouble, in their prospective fruits and advantages; or he could decide to couple the security of his fortune with the good faith of the townspeople of any substantial municipality in any continent that fancy or information might recommend. He could secure forthwith, if he wished it, cheap and comfortable means of transit to any country or climate without passport or other formality, could despatch his servant to the neighbouring office of a bank for such supply of the precious metals as might seem convenient, and could then proceed abroad to foreign quarters, without knowledge of their religion, language, or customs, bearing coined wealth upon his person, and would consider himself greatly aggrieved and much surprised at the least interference. But, most important of all, he regarded this state of affairs as normal, certain, and permanent, except in the direction of further improvement, and any deviation from it as aberrant, scandalous, and avoidable. The projects and politics of militarism and imperialism, of racial and cultural rivalries, of monopolies, restrictions, and exclusion, which were to play the serpent to this paradise, were little more than amusements of his daily newspaper, and appeared to exercise almost no influence at all on the ordinary course of social and economic life, the internationalisation of which was nearly complete in practice" (Keynes, 1919:6-7).

A eloqüente descrição de Keynes, publicada há quase 80 anos, poderia ser utilizada quase ipsis litteris para retratar muitas das pretensas novidades da economia mundial do final do século XX. Diferenças de qualidade literária à parte, há muita

9 Hirst \& Thompson, 1996, 9-10. Segundo Gerbier, a expressão “aldeia planetária” data do final do século XIX, período em que o progresso nos meios de comunicação e transporte (telégrafo, navio a vapor ou óleo combustível, trem) transtornaram consideravelmente as condições de vida. Para esse autor, as conseqüências do telégrafo, em termos de compressão do tempo e do espaço, foram mais importantes do que as dos progressos das décadas recentes no campo das telecomunicações (Gerbier, 1997, p. 27). 
semelhança entre essa passagem e o tipo de caracterização vulgarizada por textos recentes sobre "globalização".

O grau de integração da economia internacional nas décadas recentes é comparável, e em alguns aspectos até menor, do que o observado no período anterior à Primeira Guerra (10). O nível atual de integração através do comércio, por exemplo, não parece muito mais alto do que o alcançado em 1913, ainda que se possa questionar a qualidade dos dados utilizados nessas comparações (Wade, 1996:66). Um fato pouco conhecido e surpreendente é que a participação do comércio exterior na produção mundial só recuperou o nível de 1913 nos anos 70 (Bairoch \& KozulWright, 1996:5-6).

No caso dos países desenvolvidos, a relação entre as exportações de mercadorias e o PIB era de $12,9 \%$ em 1912-14, caiu para 6,2\% em 1937-39 e foi se recuperando gradativamente depois da Segunda Guerra. Em 1991-93, a participação das exportações no PIB era de 14,3\%, apenas um pouco maior do que a de 1912-14 (tabela 1). Na Europa Ocidental, a participação passou de 18,3\% do PIB em 191214 para $21,7 \%$ do PIB em $1991-93$. Nos EUA, de 6,4\% para 7,5\% do PIB. No caso do Japão, houve até mesmo queda da relação exportações / PIB, de 12,6\% em 191214 para 8,8\% em 1991-93 (11) (tabela 1).

10 Esse ponto é reconhecido em documento recente do Fundo Monetário Internacional, dedicado ao tema da "globalização": "Globalization is not a new phenomenon. Highly integrated markets contributed to the rapid growth of trade and output during the period of the gold standard prior to World War I. (...) The liberalization of trade and financial flows over the past fifty years has gradually resulted in a level of integration similar in some respects to that known at the beginning of the century - with plenty of scope for further integration as the next century approaches" (International Monetary Fund, 1997b, p. 4). De acordo com esse documento, o processo de internacionalização das décadas recentes deve ser visto como a retomada da integração intensiva que começou em meados do século XIX e terminou com a Primeira Guerra Mundial (Id., p. 45). No que se refere aos fluxos líquidos de capital e à movimentação de trabalhadores, o grau de integração atual é, inclusive, inferior ao que se observava antes da Primeira Guerra (Id., p. 46, 113 114).

11 A Unctad apresenta dados semelhantes para cinco países - os EUA, o Japão, a Alemanha, a França e o Reino Unido. A comparação dos dados de 1913 com os de 1992 mostra um aumento mais significativo da relação entre exportações e o PIB nos casos da França (de $13,9 \%$ para $17,5 \%$ ) e da Alemanha (de $17,5 \%$ para $24 \%$ ), possivelmente como reflexo dos avanços do processo de integração na Europa continental. Nos EUA, o aumento é modesto, de 6,1\% em 1913 para 7,1\% em 1992. Nos dois outros países, a relação exportações/PIB diminuiu entre 1913 e 1992: de 12,3\% para 9,2\% no caso do Japão e de $20,9 \%$ para $18,2 \%$ no do Reino Unido (United Nations Conference on Trade and Development, 1994, p. 127). 
Tabela 1

Países desenvolvidos: relação entre exportações de mercadorias e $\operatorname{PIB}\left({ }^{*}\right)$

$(\mathrm{em} \%)$

\begin{tabular}{ccccr}
\hline Ano & $\begin{array}{c}\text { Países } \\
\left.\text { Desenvolvidos }{ }^{* *}\right)\end{array}$ & EUA & Europa Ocidental & Japão \\
\hline $1889 / 1891$ & 11,7 & 6,7 & 14,9 & 5,1 \\
$1912 / 1914$ & 12,9 & 6,4 & 18,3 & 12,6 \\
$1928 / 1930$ & 9,8 & 5,0 & 14,5 & 13,6 \\
$1937 / 1939$ & 6,2 & 3,7 & 7,1 & 13,0 \\
1950 & 7,8 & 3,8 & 13,4 & 6,8 \\
1953 & 8,4 & 4,3 & 13,4 & 7,5 \\
$1959 / 1961$ & 8,6 & 3,8 & 14,8 & 8,9 \\
$1969 / 1971$ & 10,2 & 4,0 & 17,4 & 9,7 \\
$1974 / 1976$ & 14,1 & 6,6 & 21,3 & 11,0 \\
$1979 / 1981$ & 15,5 & 7,7 & 22,7 & 11,8 \\
$1989 / 1991$ & 14,6 & 7,2 & 23,0 & 9,6 \\
$1991 / 1993$ & 14,3 & 7,5 & 21,7 & 8,8 \\
\hline
\end{tabular}

(*) Agregados medidos a preços correntes

(**) Europa Ocidental, exclusive Iugoslávia, EUA, Canadá, Austrália, Nova Zelândia e Japão

Fonte: Paul Bairoch, Globalization myths and realities: one century of external trade and foreign investments. In: Robert Boyer \& Daniel Drache (eds.), States against markets: the limits of globalization. London, Routledge, 1996.

Os dados referentes a investimento direto, embora mais precários do que os de comércio, mostram um quadro semelhante. O estoque de investimentos estrangeiros diretos representou o equivalente a 9,7\% do PIB mundial em 1994 (12), um percentual próximo ao estimado para 1913 (13). Às vésperas da Primeira Guerra, os investimentos da Grã Bretanha no exterior eram maiores do que o seu estoque de capital doméstico, um recorde do qual nenhum dos principais países desenvolvidos sequer se aproximou desde então (Krugman, 1996:207).

Para os países em desenvolvimento, o investimento estrangeiro era substancial tanto em termos relativos como em termos absolutos. Calcula-se que representava provavelmente cerca de um quarto do PIB desses países na virada do século (Nayyar, 1995:6), em comparação com 12,5\% do PIB em 1994 (14). A preços de 1980, o estoque de investimento estrangeiro nos países em desenvolvimento em 1914 era de

12 United Nations Conference on Trade and Development, 1996, Annex table 6, p. 261.

13 Estima-se que, em 1913, o estoque de investimentos diretos correspondia a mais de 9\% do produto mundial (Bairoch \& Kozul-Wright, 1996, p. 10).

14 United Nations Conference on Trade and Development, 1996, Annex table 6, p. 262. 
US\$ 179 bilhões, quase o dobro dos US\$ 96 bilhões registrados em 1980 (Nayyar, 1995:6).

Diversos estudos sugerem que a tão comentada mobilidade internacional do capital desde os anos 70 é menor, em muitos aspectos, do que a que se observava antes de 1914 (Hirst \& Thompson, 1996:27-28). No final do século XIX e no início do século XX, os fluxos internacionais líquidos de capital (em contraposição a operações financeiras complexas que não financiam o investimento real) correspondiam a uma parcela consideravelmente maior da poupança mundial do que nos anos recentes (Krugman, 1996:208). Relativamente ao tamanho das economias, os movimentos líquidos de capital entre países, medidos pelos saldos de balanço de pagamentos em conta corrente, eram significativamente maiores (Nayyar, 1995:8).

Naquela época, assim como nas décadas recentes, os fluxos financeiros cresceram mais rapidamente do que o comércio e a produção. Restrições formais aos fluxos de capital eram praticamente inexistentes e a estabilidade cambial entre as economias mais avançadas, propiciada pelo padrão-ouro, favorecia a integração dos mercados financeiros (15). Estima-se que, em 1913, o movimento líquido de capitais alcançava o equivalente a $5 \%$ do PNB dos países exportadores de capital (Bairoch \& Kozul-Wright, 1996:11). A Grã Bretanha, a maior exportadora de capitais antes da Primeira Guerra, registrou um superávit médio no balanço de pagamentos em conta corrente de 5\% do PIB entre 1880 e 1913 (Nayyar, 1995:8-9). No final desse período, a exportação líquida de capitais da Grã Bretanha chegou a um ápice de $9 \%$ da renda nacional (Bairoch \& Kozul-Wright, 1996:11). Atualmente, são poucos os países que podem sustentar uma exportação ou importação líquida de capitais equivalente a mais de $3 \%$ do PIB por um período prolongado (16). Os superávits em conta corrente do Japão e da Alemanha, os dois maiores exportadores de capital nos anos 80 , chegaram a um máximo de $4 \%$ a $5 \%$ do PIB na segunda metade da década passada (17).

Em 1913-14, o estoque de créditos contra o exterior representava nada menos que 153\% do PNB da Grã Bretanha e 97\% do PNB da França (Zevin, 1992:47). Atualmente, as principais nações credoras não chegam sequer perto desses percentuais. Em 1994, o Japão, por exemplo, registrava ativos externos equivalentes a $52 \%$ do PIB em termos brutos e a $15 \%$ do PIB em termos líquidos. Os ativos externos brutos da Alemanha correspondiam a $70 \%$ do PIB e os ativos líquidos, a $10 \%$ do

15 Zevin, 1992, p. 48. Ver, também, United Nations Conference on Trade and Development, 1994, p. 120-121.

16 The Economist, 1995, p. 5.

17 International Monetary Fund, 1997b, p. 113. Entre 1980 e 1995, o Japão e a Alemanha registraram superávits médios em conta corrente de $2,2 \%$ e $1,3 \%$ do PIB, respectivamente. O superávit máximo da Alemanha nesse período foi de $4,8 \%$ do PIB, registrado em 1989. O do Japão foi de 4,3\% do PIB, em 1986 (Organisation for Economic Co-operation and Development, 1996b, Annex table 51, p. A54). 
PIB (18). Antes da Primeira Guerra, também era mais elevada a participação de emissões estrangeiras nas praças financeiras européias. Por exemplo, os títulos estrangeiros (não incluindo os de colônias britânicas) representavam $59 \%$ do valor total dos títulos negociados em Londres em 1913; na França, o percentual correspondente alcançava 53\% em 1908 (19). Apoiando-se nesses e em outros dados, um estudo comparativo concluiu que todos os indicadores disponíveis sugerem que os mercados financeiros do final do século XIX e início do século XX eram mais integrados do que em qualquer período posterior, apesar dos imensos avanços em matéria de comunicações (Zevin, 1992:48-52).

A migração internacional também era muito maior numa época em que os EUA ergueram inclusive uma Estátua da Liberdade na entrada de Nova York para dar as boas-vindas aos imigrantes (Krugman, 1996:208). Um constraste notável com a economia "global" e "sem fronteiras" de hoje, em que imigrantes originários da África, da América Latina e da Ásia enfrentam restrições cada vez mais severas, são perseguidos pela polícia e, às vezes, recebidos a tiros nas fronteiras do mundo desenvolvido.

Para alguns autores, é justamente no terreno dos fluxos de trabalhadores que reside a diferença fundamental entre a internacionalização das décadas recentes e a que ocorreu entre meados do século passado e a Primeira Guerra (Nayyar, 1995:16). Naquela época, imigrantes obtinham cidadania com facilidade. Passaportes eram raramente necessários, como lembrou Keynes na passagem acima citada. Entre 1870 e 1914, 36 milhões de pessoas deixaram a Europa, dois terços das quais foram para os EUA. Estima-se que a emigração da China e da Índia foi ainda maior nesse período (20). Medido pelo número de trabalhadores que se deslocam internacionalmente, o grau de integração dos mercados de trabalho era muito maior no início do século do que é hoje (21).

18 Organisation for Economic Co-operation and Development, 1996b, Annex table 53, p. A56; Ministério do Planejamento e Orçamento, 1996, Tabela 1, p. 23. O Reino Unido apresentava, em 1994, ativos externos equivalentes a $115 \%$ do PIB em termos brutos, mas a apenas $2 \%$ do PIB em termos líquidos. Os demais países do G-7 são todos devedores externos em termos líquidos. Os EUA detinham ativos externos brutos correspondentes a 36\% do PIB em 1994, mas registravam uma posição líquida negativa equivalente a $12 \%$ do PIB (Id., Ibid.).

19 United Nations Conference on Trade and Development, 1994, p. 121. Em alguns mercados financeiros menores na Europa, a proporção de títulos estrangeiros era ainda mais alta (Id., Ibid.). Em Amsterdã, por exemplo, a proporção de emissões que não eram nem holandesas nem de colônias da Holanda foi de 82\% em 1855, 77\% em 1875 e $53 \%$ em 1900 (Zevin, 1992, p. 51).

20 United Nations Conference on Trade and Development, 1994, p. 120. Ver, também, Nayyar, 1995, p. 16-17.

21 International Monetary Fund, 1997b, p. 46. Segundo a Unctad, com o crescimento mais lento das economias desenvolvidas desde o início dos anos 70 e o endurecimento das leis de imigração, "os mercados de trabalho permanecem significativamente menos internacionais do que antes da Primeira Guerra Mundial" (United Nations Conference on Trade and Development, 1994, p. 129). 
Recentemente, o governo dos Estados Unidos divulgou uma pesquisa sobre a população nascida no exterior e residente naquele país. Em março de 1996, 9,3\% da população dos EUA era nascida no exterior, de pais não-americanos, em comparação com 14,7\% em 1910. Como se vê no gráfico 1, embora a proporção de pessoas nascidas no exterior venha aumentando de forma significativa desde 1970, o percentual de 1996 ainda é substancialmente inferior aos registrados pelos censos decenais do governo dos EUA em toda a segunda metade do século XIX e nas primeiras três décadas do século XX (22).

Gráfico 1

Porcentagem da população dos EUA nascida no exterior

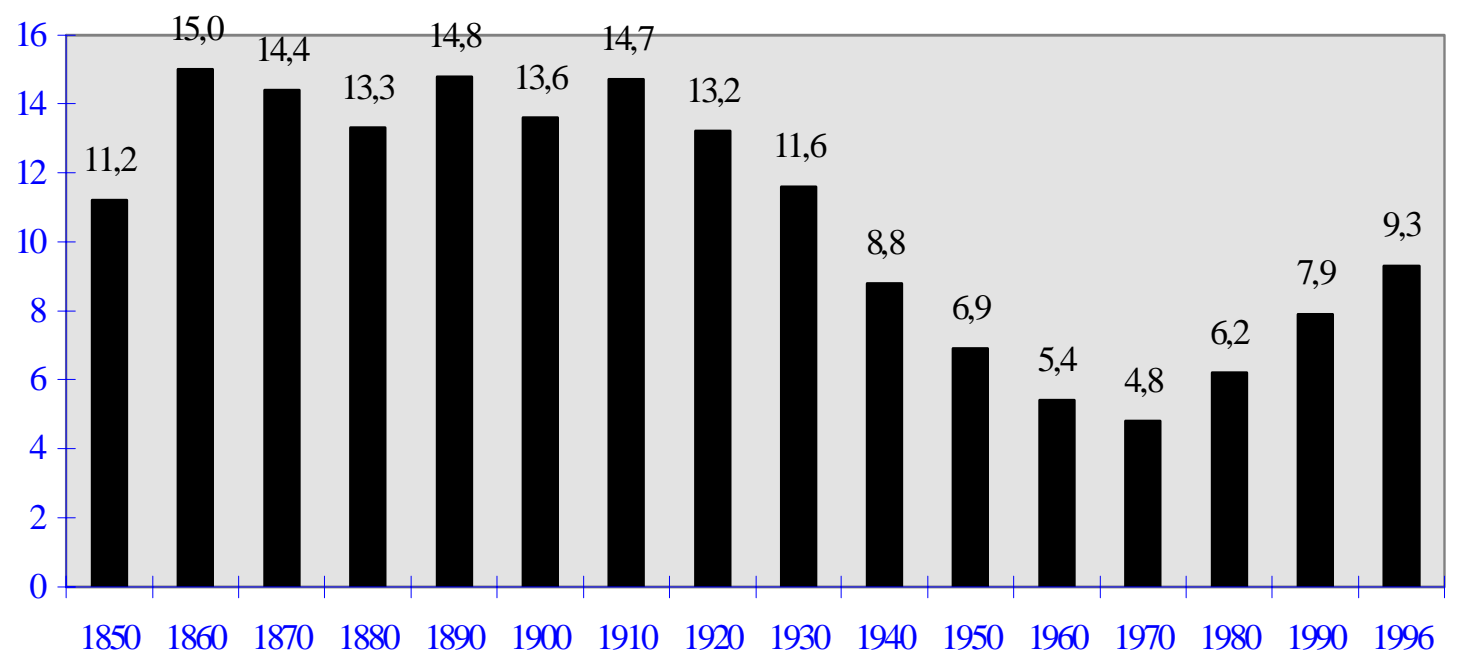

Fonte: U.S. Bureau of the Census.

22 U.S. Bureau of the Census, 1997, p. 1. Os dados dos censos da segunda metade do século XIX foram fornecidos por Kristin A. Hansen, do U.S. Bureau of the Census. 
Se tudo isso é verdade, por que prevalece a impressão de que o processo de internacionalização das últimas duas ou três décadas constitui fenômeno inédito? A ilusão decorre, pelo menos em parte, do fato de que a integração alcançada no passado recente é realmente muito significativa quando comparada ao baixo grau de abertura das economias logo após a Segunda Guerra Mundial (Krugman, 1996:208). Entre 1914 e 1950, as guerras mundiais, a Grande Depressão, a adoção do planejamento centralizado em boa parte do planeta, o nacionalismo e o protecionismo destruíram a economia internacionalizada da belle époque (23), acontecimento que bem poderia merecer alguma consideração da parte dos crentes na irreversibilidade dos processos históricos.

\section{Fronteiras da "globalização"}

Além de não ser um fenômeno inteiramente novo, o processo recente de integração das economias nacionais não tem o alcance que sugere o uso indiscriminado do termo "globalização". O grau de internacionalização alcançado nos últimos 20 ou 30 anos é, na realidade, bem menor do que geralmente se imagina.

Apesar da rápida expansão das transações econômicas internacionais, os mercados internos continuam preponderantes, sobretudo nas economias maiores. $\mathrm{Na}$ economia mundial, a demanda interna dos países absorve cerca de $80 \%$ da produção. Responde, também, por $90 \%$ dos empregos. A poupança doméstica financia mais de 95\% da formação de capital (Ferrer, 1995:13). Os mercados de trabalho permanecem altamente segmentados por políticas restritivas de imigração e barreiras lingüísticas, culturais e outros obstáculos à movimentação internacional de trabalhadores. Mesmo no terreno financeiro, a internacionalização dos mercados ainda é relativamente limitada. Como veremos mais à frente, os mercados de capitais permanecem segmentados por critérios nacionais. O grosso da poupança fica nos países onde é gerada e grande parte dos crescentes fluxos internacionais é constituída de capitais voláteis, que se movem com rapidez em resposta a mudanças nas condições financeiras e cambiais.

Talvez seja útil retomar distinção conceitual proposta por Paul Hirst e Grahame Thompson em obra já citada (Hirst \& Thompson, 1996:7-13). Esses autores sugerem que se evite confundir dois "tipos ideais": a) a economia global; e b) a economia internacional. Uma economia global seria caracterizada por alto grau de integração dos mercados e pelo predomínio das atividades transnacionais. Seria uma economia em que a influência de grandes empresas transnacionais, desvinculadas de bases do-

23 International Monetary Fund, 1997b, p. 4. No mesmo sentido, o economista Lawrence Summers, subsecretário do Tesouro dos EUA para assuntos internacionais, observou que "those enamored with globalization would do well to remember that while trade and investment rates are now far greater than they were a decade or two or three ago, they are about where they were a century ago. Much of integration of the last 50 years represents repair of the disintegration caused by misguided policies and ideologies during the dark 1914-45 years" (Summers, 1994, p. 420). 
mésticas, teria chegado ao ponto de dissolver, ou pelo menos começar a dissolver as fronteiras, reduzindo drasticamente o poder de intervenção dos Estados nacionais (24).

Já a economia internacional se caracteriza fundamentalmente por processos de intercâmbio entre economias nacionais distintas. As trocas internacionais são significativas e crescentes, mas predominam as atividades econômicas internas. A maioria das empresas não perde as suas vinculações nacionais. Os governos, agindo isoladamente ou por meio de acordos e entidades intergovernamentais, continuam a desempenhar funções econômicas essenciais. Nesse contexto, o desempenho macroeconômico dos países, em áreas como crescimento, emprego e inflação, assim como a competitividade de firmas e setores, decorrem substancialmente de processos que ocorrem em nível nacional.

O que temos hoje é uma economia internacional e não uma economia global. Não há fundamento para as alegações de que teria surgido, nos últimos 20 ou 30 anos, uma economia global, fortemente integrada, na qual os Estados nacionais estariam se tornando obsoletos e impotentes. Quem examinar com isenção os dados revelantes, não tardará a perceber a fragilidade desse ponto de vista.

A maior parte da produção mundial de bens e serviços consiste, como já foi indicado, de produção voltada para os mercados internos. A não ser no caso de países pequenos, a participação do comércio exterior no PIB é bastante limitada. As exportações equivalem a $12 \%$ ou menos do PIB nos EUA, no Japão e na União Européia (exclusive exportações intra-União Européia); os coeficientes médios para a Ásia e a América Latina são inferiores a 10\% (25). Como vimos, considerando-se apenas as exportações de mercadorias, o grau de abertura é um pouco maior do que $20 \%$ na Europa Ocidental, quando se inclui as exportações intra-européias, e da ordem de 8 a 9\% no caso dos EUA e do Japão. Medido dessa maneira, o grau de abertura das economias desenvolvidas cresceu de forma praticamente contínua entre o final da Segunda Guerra Mundial e 1980. A partir daí, a relação exportações / PIB diminuiu um pouco nos EUA e na Europa Ocidental e de forma significativa no Japão. Nos EUA, a relação média entre as exportações de mercadorias e o PIB, medidos a preços correntes, diminuiu de 7,7\% em 1979-81 para 7,5\% em 1991-93; na Europa Ocidental, de $22,7 \%$ para $21,7 \%$; no Japão, de $11,8 \%$ para $8,8 \%$ (tabela 1$)$.

24 Definição semelhante é apresentada por Paul Bairoch e Richard Kozul-Wright: “A rigor, uma economia verdadeiramente global é uma economia dominada por firmas e instituições financeiras transnacionais, operando em mercados mundiais independentemente de fronteiras nacionais, objetivos políticos nacionais e restrições econômicas domésticas" (Bairoch \& Kozul-Wright, 1996, p. 3).

25 Wade, 1996, p. 66. Em 1995, as exportações de bens e serviços representaram o equivalente a 11,1\% do PIB dos EUA; as importações, 12,5\%. Na União Européia, as exportações e as importações de bens e serviços corresponderam, em 1995, a 24\% e 23,8\% do PIB, respectivamente. Quando se exclui do cálculo as exportações dentro da União Européia, a relação cai para 8,9\% (World Trade Organization, 1996, p. 28, 41, 42, 141). 
Esses coeficientes relativamente baixos de abertura refletem, em parte, o fato de que, nos países desenvolvidos, uma parcela crescente do PIB consiste de serviços, grande parte dos quais são non-tradeables, isto é, não-transacionáveis internacionalmente. O grau de abertura é maior quando o comércio de mercadorias é comparado à produção de mercadorias transacionáveis internacionalmente. Mas é notável que, mesmo para bens tradeables, estudos empíricos têm encontrado, consistentemente, diferenças grandes e persistentes de preços entre os mercados nacionais (26). Essas diferenças podem ser atribuídas a fatores como barreiras tarifárias e não-tarifárias e custos de transporte e informação. Assim, o grau de integração dos mercados internacionais ainda é claramente inferior ao dos mercados domésticos de bens (27).

Quanto aos mercados de trabalho, o quadro geral, como já foi indicado, é de introversão. Nas décadas de 50 e 60, ainda houve um montante limitado de migração internacional de trabalhadores dos países em desenvolvimento para os países desenvolvidos, atribuível em grande medida à escassez de mão-de-obra na Europa de pós-guerra e, em alguns casos, a ligações pós-coloniais reforçadas por uma língua comum. Dos anos 70 em diante, entretanto, a migração internacional foi severamente limitada por leis draconianas de imigração e práticas consulares restritivas (28). Desde então, o movimento internacional de trabalhadores tem afetado apenas uma pequena parcela da força mundial de trabalho (29).

Em muitos países desenvolvidos, refletindo o aumento da imigração ilegal, os residentes nascidos no exterior vêm aumentando como proporção da população total. Mas a sua participação ainda é inferior a $5 \%$ na maioria dos países e ultrapassa $10 \%$ em apenas quatro (30). Como vimos, nos EUA, a população nascida no exterior, de pais não-americanos, não chega a $10 \%$ do total, um percentual bem inferior aos registrados pelos censos decenais entre 1850 e 1930.

No que se refere a investimentos diretos, o quadro geral também é de amplo predomínio dos fluxos internos e da dimensão nacional. A despeito da acentuada expansão recente, os investimentos diretos dos países desenvolvidos no exterior ain-

26 International Monetary Fund, 1997b, p. 46. A convergência de preços só se verifica no caso de commodities altamente homogêneas, como o ouro. (Id., Ibid.).

27 Id., Ibid..

28 Nayyar, 1995, p. 17.

29 United Nations Conference on Trade and Development, 1994, p. 129. Além disso, ao contrário do que acontecia no período anterior à Primeira Guerra, quando os imigrantes, em sua maioria, tornavam-se residentes permanentes, é provável que a maior parte da imigração do período recente tenha caráter temporário (Id., Ibid.). Segundo Nayyar, a única evidência significativa de mobilidade internacional do trabalho nos últimos 25 anos é a migração temporária de trabalhadores para a Europa, o Oriente Médio e o Leste Asiático (Nayyar, 1995, p. 17). Mais cauteloso, o já citado documento recente do FMI limita-se a observar que "não parece que os mercados de trabalho tenham se tornado mais integrados nas décadas recentes" (International Monetary Fund, 1997b, p. 46).

30 Id., Ibid.. 
da são bastante inexpressivos como proporção do investimento doméstico líquido das empresas. Tipicamente, a ordem de magnitude ficou entre $5 \%$ e $15 \%$ nos anos 80. O Reino Unido, com $65 \%$, é um caso excepcional. Os investimentos diretos recebidos pelos países desenvolvidos do exterior também são pequenos relativamente ao investimento das firmas, variando entre $0,5 \%$ no caso do Japão e $14 \%$ nos EUA. Em outras palavras, o investimento doméstico realizado pelo capital nacional prevalece amplamente tanto sobre o investimento no exterior, como sobre o investimento recebido do exterior (Wade, 1996:70-73).

Nos anos 90, o quadro geral não se modificou. Estatísticas da Unctad, referentes à relação entre investimento direto estrangeiro e formação bruta de capital, indicam que a participação dos fluxos internacionais ainda é bastante modesta. A ampliação do estoque de capital continua resultando essencialmente do investimento nacional. Para a economia mundial como um todo, a relação entre investimento internacional e formação bruta de capital fixo foi de apenas 3,9\% em 1994 , contra 3,1\% em média no período 1984-89 (31). No caso dos países desenvolvidos, os investimentos diretos recebidos do exterior corresponderam a $3,3 \%$ do investimento bruto em 1994, um percentual inferior ao observado em 1984-89 (tabela 2).

O Japão, que é das economias do Grupo dos 7 a mais fechada a capital estrangeiro, acolheu montantes irrisórios de investimento direto do exterior, nunca mais do que o equivalente a $0,3 \%$ da formação de capital. Entre os países do G-7, apenas o Reino Unido recebeu, em média, investimentos diretos equivalentes a mais de $10 \%$ da formação de capital no período 1990-94 (tabela 3). Considerando o conjunto dos países desenvolvidos, somente duas economias pequenas - Bélgica-Luxemburgo e Nova Zelândia - registraram investimentos diretos do exterior superiores a $20 \%$ do investimento total no período 1990-94 (32).

Os investimentos realizados no exterior representam uma proporção um pouco maior do investimento total dos países desenvolvidos. Mas a importância relativa do investimento internacional declinou ao longo dos anos 90 , caindo de $6,5 \%$ da formação de capital em 1990 para 4,8\% em 1994 para o conjunto desses países (tabela 2). Entre os países do G-7, o único que investe mais pesadamente no exterior é o Reino Unido (tabela 3).

31 Investimento direto estrangeiro em determinado país é definido como um influxo de capital que implica uma relação de longo prazo e controle do empreendimento por parte de investidor residente fora do país. Os dados da Unctad incluem lucros reinvestidos e empréstimos intracompanhias (United Nations Conference on Trade and Development, 1996, p. 219-220). A formação bruta de capital fixo é medida a preços correntes (Id., p. 225).

$32 \mathrm{O}$ investimento direto recebido do exterior representou, nesse período, 22,3\% da formação de capital no caso da Bélgica e do Luxemburgo e $24,2 \%$ no caso da Nova Zelândia (Id., Annex table 5, p. 249-250). 
Tabela 2

Fluxos de investimento direto estrangeiro como proporção da formação bruta de capital fixo

(por regiões, em \%)

\begin{tabular}{|c|c|c|c|c|c|c|}
\hline Região & $1984-1989^{(1)}$ & 1990 & 1991 & 1992 & 1993 & 1994 \\
\hline \multicolumn{7}{|l|}{ MUNDO } \\
\hline do exterior & 3,1 & 4,0 & 3,1 & 3,2 & 3,8 & 3,9 \\
\hline no exterior & 3,3 & 4,7 & 4,2 & 3,9 & 4,2 & 4,0 \\
\hline \multicolumn{7}{|c|}{ Países desenvolvidos } \\
\hline do exterior & 3,9 & 4,9 & 3,3 & 3,1 & 3,5 & 3,3 \\
\hline no exterior & 4,7 & 6,5 & 5,8 & 5,0 & 5,2 & 4,8 \\
\hline \multicolumn{7}{|c|}{ Europa Ocidental } \\
\hline do exterior & 4,6 & 7,0 & 5,4 & 5,4 & 5,7 & 4,8 \\
\hline no exterior & 7,8 & 9,4 & 7,8 & 7,6 & 7,5 & 8,0 \\
\hline \multicolumn{7}{|c|}{ América do Norte(2) } \\
\hline do exterior & 5,8 & 6,1 & 2,9 & 2,5 & 4,7 & 4,9 \\
\hline no exterior & 2,6 & 3,5 & 4,6 & 4,8 & 7,6 & 4,4 \\
\hline \multicolumn{7}{|c|}{ Outros paises desenvolvidos ${ }^{(3)}$} \\
\hline do exterior & 0,7 & 1,0 & 0,7 & 0,8 & 0,4 & 0,6 \\
\hline no exterior & 3,5 & 4,8 & 4,1 & 1,9 & 1,2 & 1,9 \\
\hline \multicolumn{7}{|c|}{ Países em desenvolvimento } \\
\hline do exterior & 2,8 & 3,2 & 4,0 & 4,8 & 6,3 & 7,5 \\
\hline no exterior & 1,0 & 1,7 & 0,9 & 2,2 & 3,0 & 3,4 \\
\hline \multicolumn{7}{|l|}{ África } \\
\hline do exterior & 3,6 & 2,7 & 4,2 & 4,4 & 4,9 & 7,5 \\
\hline no exterior & 1,4 & 1,7 & 1,5 & 0,5 & 1,1 & 0,9 \\
\hline \multicolumn{7}{|c|}{ América Latina e Caribe } \\
\hline do exterior & 4,2 & 4,0 & 6,4 & 7,2 & 6,3 & 8,6 \\
\hline no exterior & 0,4 & 2,0 & $-0,2$ & 1,5 & 0,9 & 1,3 \\
\hline \multicolumn{7}{|l|}{ Ásia } \\
\hline do exterior & 2,3 & 3,1 & 3,4 & 4,1 & 6,5 & 7,2 \\
\hline no exterior & 1,2 & 1,6 & 1,2 & 2,6 & 3,9 & 4,3 \\
\hline \multicolumn{7}{|c|}{ Europa Centrale Oriental } \\
\hline do exterior & $(-)$ & $(-)$ & 0,4 & 0,6 & 0,9 & 0,9 \\
\hline no exterior & $(-)$ & $(-)$ & $(-)$ & $(-)$ & $(-)$ & 0,1 \\
\hline
\end{tabular}

(1) Média anual.

(2) Exclui México.

(3) África do Sul, Austrália, Israel, Japão e Nova Zelândia.

(-) Dados iguais a ou próximos de zero.

Fonte: United Nations Conference on Trade and Development, World investment report, 1996. 
Tabela 3

Fluxos de investimento direto estrangeiro como proporção da formação bruta de capital fixo, grupo dos 7 e países em desenvolvimento selecionados

(Em \%)

\begin{tabular}{|c|c|c|c|c|c|c|c|}
\hline Países & & $1984-1989^{(1)}$ & 1990 & 1991 & 1992 & 1993 & 1994 \\
\hline \multicolumn{8}{|l|}{ Grupo dos 7} \\
\hline \multirow{2}{*}{ Alemanba } & do exterior & 1,0 & 0,9 & 1,2 & 0,6 & 0,1 & $-0,9$ \\
\hline & no exterior & 5,2 & 7,7 & 7,0 & 5,2 & 3,9 & 4,2 \\
\hline \multirow[t]{2}{*}{ Canadá } & do exterior & 5,4 & 6,5 & 2,4 & 4,2 & 5,0 & 5,9 \\
\hline & no exterior & 5,3 & 3,9 & 4,9 & 3,4 & 5,8 & 4,7 \\
\hline \multirow[t]{2}{*}{$E U A$} & do exterior & 5,8 & 6,0 & 3,0 & 2,2 & 4,7 & 4,8 \\
\hline & no exterior & 2,2 & 3,4 & 4,5 & 4,9 & 7,8 & 4,4 \\
\hline \multirow[t]{2}{*}{ França } & do exterior & 3,5 & 5,2 & 5,9 & 8,2 & 8,9 & 7,1 \\
\hline & no exterior & 5,8 & 13,6 & 9,4 & 11,8 & 8,8 & 9,4 \\
\hline \multirow[t]{2}{*}{ Itália } & do exterior & 2,0 & 2,8 & 1,0 & 1,3 & 1,6 & 0,9 \\
\hline & no exterior & 2,1 & 3,3 & 3,1 & 2,5 & 3,2 & 2,2 \\
\hline \multirow[t]{2}{*}{ Japão } & do exterior & $(-)$ & 0,2 & 0,2 & 0,3 & $(-)$ & 0,1 \\
\hline & no exterior & 3,4 & 5,1 & 4,0 & 2,0 & 1,2 & 1,4 \\
\hline \multirow[t]{2}{*}{ Reino Unido } & do exterior & 11,5 & 17,0 & 9,4 & 9,1 & 10,2 & 6,6 \\
\hline & no exterior & 19,8 & 10,1 & 9,5 & 11,6 & 18,1 & 16,5 \\
\hline \multicolumn{8}{|c|}{ PAÍ́SES EM DESENVOLVIMENTO SELECIONADOS ${ }^{(2)}$} \\
\hline \multirow[t]{2}{*}{ Argentina } & do exterior & 3,8 & 24,2 & 15,1 & 41,7 & 56,1 & 9,6 \\
\hline & no exterior & 0,2 & 0,7 & $-0,3$ & 0,5 & $-0,2$ & 0,3 \\
\hline \multirow[t]{2}{*}{ Brasil } & do exterior & 2,3 & 1,0 & 1,4 & 3,0 & 1,3 & 3,0 \\
\hline & no exterior & 0,3 & 0,7 & 1,3 & 0,2 & 0,5 & 1,0 \\
\hline \multirow[t]{2}{*}{ Chile } & do exterior & 15,6 & 8,3 & 7,3 & 7,2 & 7,2 & 19,9 \\
\hline & no exterior & 0,2 & 0,1 & 1,7 & 3,9 & 3,7 & 7,0 \\
\hline \multirow[t]{2}{*}{ China } & do exterior & 1,8 & 2,6 & 3,3 & 7,8 & 20,0 & 24,5 \\
\hline & no exterior & 0,5 & 0,6 & 0,7 & 2,8 & 3,2 & 1,5 \\
\hline \multirow[t]{2}{*}{ Cingapura } & do exterior & 28,3 & 47,1 & 33,5 & 13,3 & 24,6 & 23,5 \\
\hline & no exterior & 3,6 & 17,2 & 7,0 & 7,4 & 8,8 & 9,2 \\
\hline \multirow[t]{2}{*}{ Indonésia } & do exterior & 1,6 & 2,8 & 3,6 & 3,9 & 3,8 & 3,6 \\
\hline & no exterior & 0,1 & $(-)$ & $(-)$ & 0,1 & $(-)$ & $(-)$ \\
\hline \multirow[t]{2}{*}{ Malásia } & do exterior & 8,8 & 23,8 & 23,8 & 26,0 & 22,5 & 16,1 \\
\hline & no exterior & 2,6 & 3,8 & 2,3 & 2,6 & 5,9 & 6,7 \\
\hline \multirow[t]{2}{*}{ México } & do exterior & 7,8 & 5,6 & 8,5 & 6,4 & 6,0 & 10,4 \\
\hline & no exterior & 0,4 & 0,5 & 0,3 & 1,1 & $(-)$ & 1,4 \\
\hline
\end{tabular}

(1) Média anual.

(2) Países que receberam, em 1995, mais de U\$ 3 bilhões de investimentos diretos do exterior.

(-) Dados iguais a ou próximos de zero.

Fonte: United Nations Conference on Trade and Development, World investment report, 1996. 
No caso dos países em desenvolvimento, a proporção é algo maior, mas também não é nem de longe dominante. Para os países em desenvolvimento como um todo, a relação entre investimentos diretos recebidos do exterior e formação bruta de capital fixo, embora crescente, correspondeu a apenas 7,5\% em 1994. Na América Latina e na Ásia, regiões que recebem o grosso dos investimentos diretos destinados aos países em desenvolvimento, o investimento estrangeiro representou, em 1994, $8,6 \%$ e $7,2 \%$ da formação bruta de capital fixo, respectivamente (tabela 2 ). No caso do Brasil, o investimento estrangeiro correspondeu a apenas 3\% da formação de capital em 1994 (tabela 3).

Entre 1990 e 1994, num total de 147 países em desenvolvimento, apenas dois países pequenos - a Guiné Equatorial e a Libéria - registraram ingressos de investimentos correspondentes a mais de $50 \%$ da formação bruta de capital fixo. Somente 18 países, a maioria pequenos, receberam investimentos diretos equivalentes a mais de $20 \%$ da formação de capital nesse período (33). Note-se, além disso, que esses dados tendem a superestimar a contribuição do investimento estrangeiro à formação de capital nos países desenvolvidos e sobretudo nos países em desenvolvimento, uma vez que os investimentos diretos incluem fluxos relacionados a operações de privatização e outras aquisições de empresas preexistentes (34).

Em suma, na imensa maioria das economias a ampliação do estoque de capital se realiza preponderantemente com base em decisões nacionais de investimento. Por esses e outros motivos, a dinâmica macroeconômica continua a refletir fundamentalmente o que se passa dentro das fronteiras nacionais. Tendo em vista o grau ainda relativamente limitado de integração internacional, sobretudo nas economias de maior porte, não é de surpreender que as flutuações cíclicas do nível de emprego e da atividade econômica não estejam sincronizadas. Nos 10 últimos anos, as variações das taxas de desemprego da mão-de-obra e de crescimento do PIB real das três principais economias, por exemplo, têm apresentado divergências marcadas (gráfi$\cos 2$ e 3). Essa assincronia ajuda a entender - diga-se de passagem - as crônicas dificuldades de coordenar as políticas macroeconômicas do G-7 e a preferência por um regime de flutuação cambial entre o dólar, o iene e as moedas européias, ponto ao qual voltaremos na seção 7 deste trabalho.

33 Id., Annex table 5, p. 251-259.

$34 \mathrm{O}$ relatório da Unctad destaca a privatização como um dos fatores responsáveis pelo crescimento recente do ingresso de investimentos diretos estrangeiros nos países em desenvolvimento. Na América Latina, a concentração dos investimentos em certos setores (indústria automobilística nos casos do México e do Brasil e recursos naturais no do Chile) e o peso dos influxos associados à privatização (nos casos da Argentina, Peru e Venezuela) tornam o investimento direto propenso a substanciais flutuações de ano para ano. Na Argentina, Peru e Venezuela, por exemplo, houve aumento expressivo do ingresso de investimentos estrangeiros quando algumas grandes companhias estatais foram privatizadas no início dos anos 90 (ver tabela 3 para dados da Argentina). Nos anos seguintes, contudo, registrou-se diminuição considerável das entradas relacionadas a privatizações, o que foi compensado apenas em parte por investimentos pós-privatização (Id., p. xvii-Xviii). 
GRÁFICO 2: TAXAS DE DESEMPREGO PADRONIZADAS

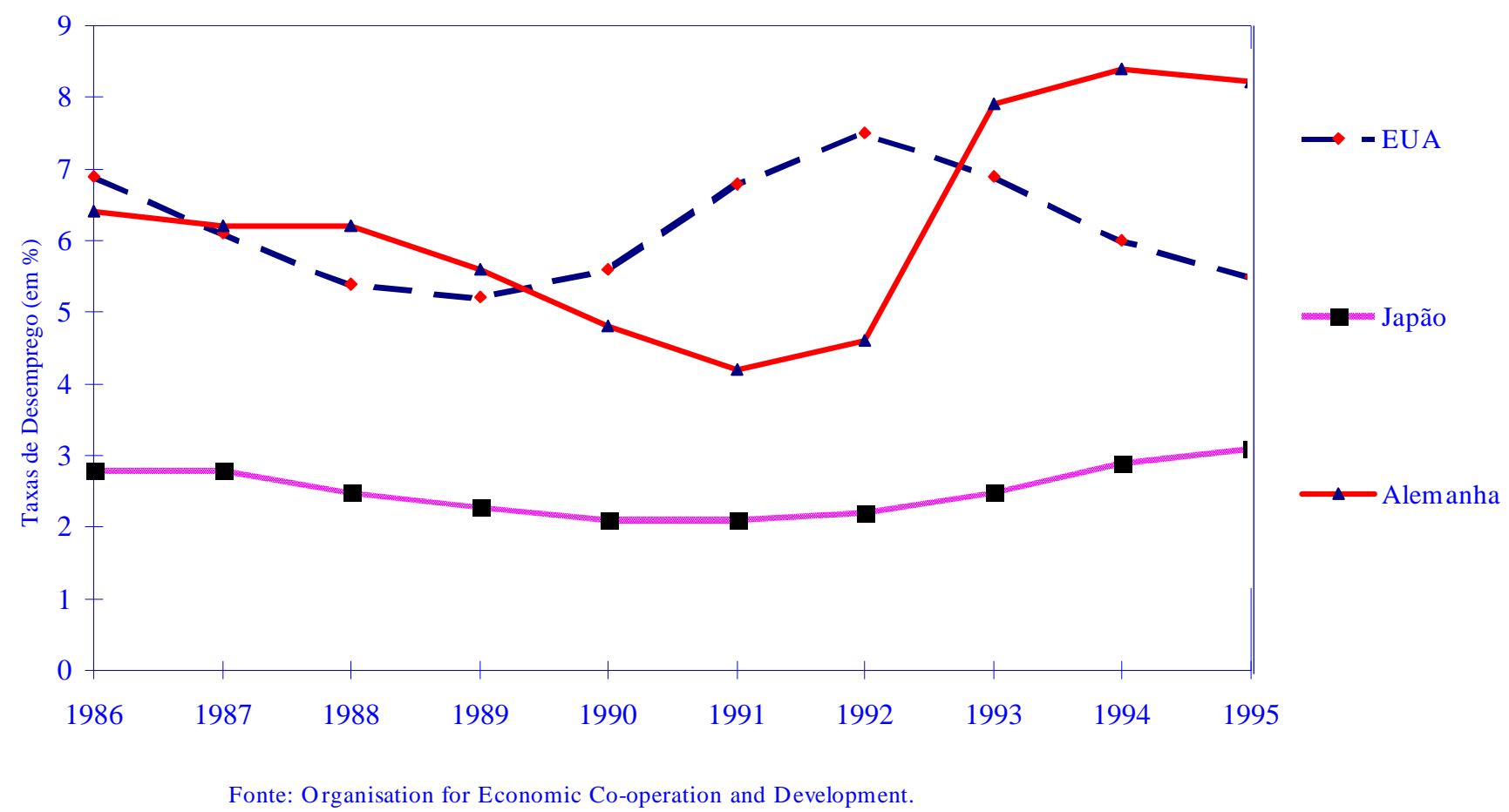




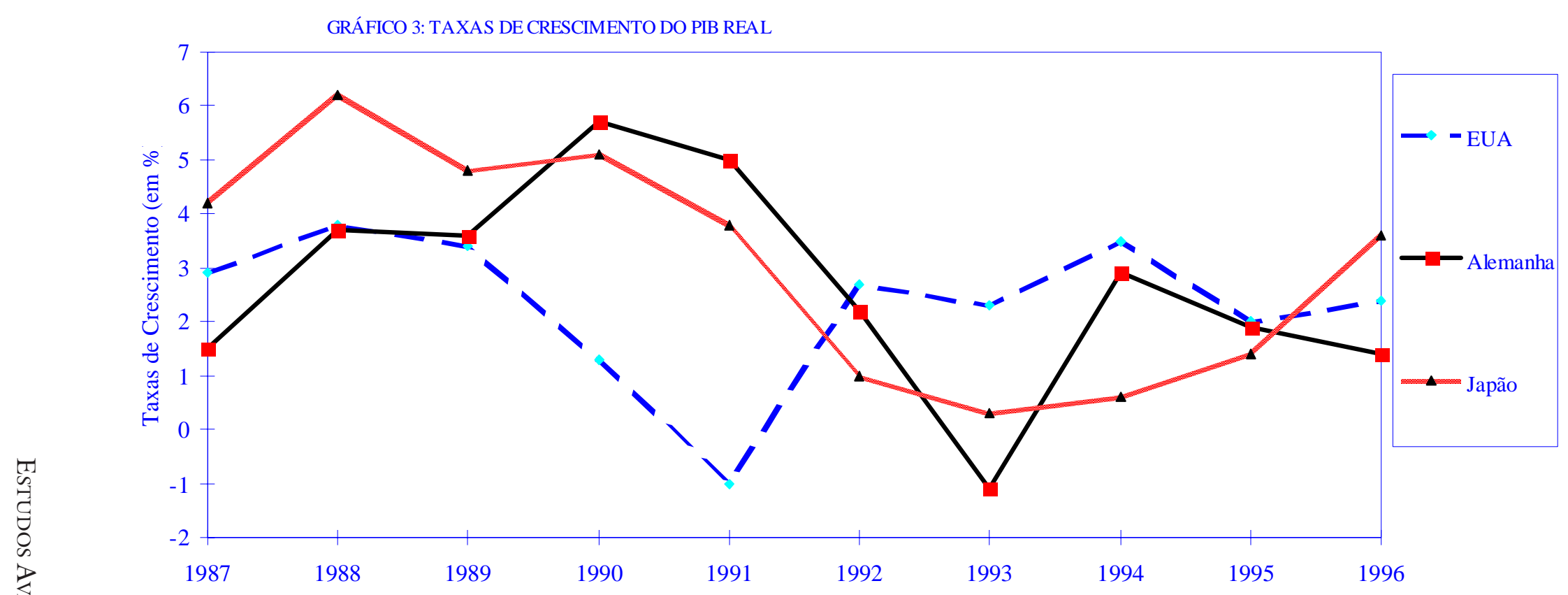

Fonte: Organisation for Economic Co-operation and Development. 
A despeito da suposta "globalização", movimentos divergentes dos hiatos de produto indicam que as correlações entre as flutuações cíclicas das principais economias avançadas não aumentaram nos anos recentes (35). As correlações foram, inclusive, mais altas nos anos 70, quando essas economias estiveram submetidas a fortes choques externos do lado da oferta, em função dos aumentos abruptos do preço do petróleo. Excetuados períodos em que prevalece a influência de choques comuns, como choques tecnológicos ou de preços de commodities, as flutuações cíclicas ainda são comandadas por fatores domésticos não-sincronizados (36).

A tese de que o desemprego é um fenômeno mundial, produto da inexorável "globalização", também não encontra apoio nos dados. As estatísticas dos países desenvolvidos, por exemplo, mesmo quando padronizadas, mostram enormes discrepâncias em termos de taxas de desemprego aberto. Há países com problemas graves, até gravíssimos, de desemprego, como a Espanha, a França e a Itália. No entanto, em outros países, notadamente nos EUA e no Japão, as taxas de desemprego são relativamente baixas (37).

Não se observa tampouco uma tendência generalizada de aumento do desemprego nas economias mais adiantadas. EUA, Reino Unido, Canadá e Austrália, por exemplo, vêm registrando significativa diminuição das taxas de desemprego desde 1992 ou 1993 (38). No mundo desenvolvido, o desemprego em massa é, essencialmente, um problema da Europa continental, decorrente em grande medida da rigidez arbitrária dos critérios de convergência estabelecidos, por insistência da Alemanha, no Tratado de Maastricht. Mas mesmo nessa região os números diferem enormemente de país para país. Em 1995, as taxas de desemprego na Europa continental variavam de $4,9 \%$ na Noruega até $22,7 \%$ na Espanha (39).

Na América Latina, os dados de desemprego são de menor qualidade e abrangência e menos comparáveis internacionalmente. Feita essa ressalva, as estatísticas dos governos latino-americanos, publicados pela Cepal, também mostram grandes variações de economia para economia. Em 1996, as taxas de desemprego urbano variavam entre $3,5 \%$ na Bolívia e $17,2 \%$ na Argentina (40).

Apesar de tudo que tem sido dito sobre o efeito avassalador das tendências "globais", o desempenho do mercado de trabalho reflete, no essencial, processos que ocorrem em âmbito nacional, ou no máximo regional, especialmente nas economias maiores. A questão do desemprego, assim como tantas outras, continua a depender fundamentalmente da evolução da economia doméstica e da eficácia das políticas econômicas e sociais.

35 International Monetary Fund, 1997b, p. 70

36 Id., Ibid.

37 Organisation for Economic Co-operation and Development, 1997, Annex table 22, p. A25.

38 Id., Annex table 21, p. A24.

39 Id., Annex table 22, p. A25.

40 Comisión Económica para América Latina y el Caribe, 1996, Cuadro A.4, p. 42. 
Para esse ponto alertou o último relatório anual da Organização Internacional do Trabalho (OIT), quando criticou os "exageros sensacionalistas" a respeito do impacto das variáveis internacionais sobre os mercados de trabalho. Ainda é relativamente pequeno o número de trabalhadores empregados em atividades ligadas ao mercado internacional. Nos países desenvolvidos, uma média de quase 70\% dos trabalhadores estão no setor de serviços, a maior parte do qual consiste de atividades non-tradeable. Nos países em desenvolvimento de baixa-renda, o grosso do emprego ainda é gerado pela agricultura tradicional ou de subsistência e pelo setor urbano informal, e não pelo setor produtor de tradeables (41). Não é verdade, ressalta a OIT, que a "globalização" seja uma força supranacional irresistível que tenha usurpado, em grande medida, a autonomia dos governos. As políticas nacionais ainda são a influência dominante nos resultados em termos econômicos e de mercado de trabalho (42).

\section{Distribuição geográfica do comércio e dos movimentos de capital}

Os dados sobre a distribuição geográfica do comércio de bens e serviços e dos movimentos de capital também não são, nem de longe, consistentes com a propalada imagem de uma integração econômica global. O comércio internacional está fortemente concentrado nos países desenvolvidos, e essa concentração tem aumentado no passado recente. EUA, Canadá, Japão e Europa Ocidental respondiam por 69,8\% das exportações e 68,9\% das importações mundiais de mercadorias em 1995, em comparação com 61,1\% das exportações e 67,1\% das importações em 1980 (tabelas 4 e 5). No que se refere ao comércio de serviços, a participação desses países é ainda maior (tabelas 6 e 7 ).

No campo financeiro, a distribuição geográfica também é muito desigual. Entre 1993 e 1995, os países desenvolvidos responderam, em média, por 73,8\% do valor líquido da emissão internacional de títulos e $78 \%$ do valor dos empréstimos internacionais sindicalizados anunciados. Nesse período, os países em desenvolvimento participaram com apenas $15,1 \%$ do valor dos títulos emitidos e $16,6 \%$ do valor dos empréstimos sindicalizados (43). Em dezembro de 1995, os países desenvolvidos respondiam por $81,3 \%$ do estoque de títulos internacionais em circulação; os países em desenvolvimento, por 6,9\% (44).

41 International Labour Office, 1996, p. 5.

42 Id., p. xiv, 1, 2, 8, 10.

43 International Monetary Fund, 1996b, p. 57, 74. No que se refere à emissão internacional de ações, a participação dos países em desenvolvimento foi maior nesse período, tendo alcançado $32,4 \%$, em média (Id., p. 101 ).

44 Id., p. 57. 
Tabela 4

Exportações de mercadorias ${ }^{(1)}$, por regiões e países

(Em U\$ bilhões e em \%)

\begin{tabular}{|c|c|c|c|c|c|}
\hline & \multirow{2}{*}{$\begin{array}{l}\text { Valor } \\
1995\end{array}$} & \multicolumn{4}{|c|}{ Participação } \\
\hline & & 1980 & 1985 & 1990 & 1995 \\
\hline Mundo $^{(2)}$ & 4890 & 100,0 & 100,0 & 100,0 & 100,0 \\
\hline América do Norte & 777 & 14,5 & 16,0 & 15,4 & 15,9 \\
\hline EUA & 584 & 11,1 & 11,3 & 11,6 & 11,9 \\
\hline Europa Ocidental & 2191 & 40,2 & 40,1 & 48,3 & 44,8 \\
\hline Ásia & 1301 & 15,6 & 20,8 & 21,8 & 26,6 \\
\hline Japão & 443 & 6,4 & 9,1 & 8,5 & 9,1 \\
\hline China & 149 & 0,9 & 1,4 & 1,8 & 3,0 \\
\hline América Latina & 224 & 5,4 & 5,6 & 4,3 & 4,6 \\
\hline Brasil & 47 & $(.)$. & 1,3 & 0,9 & 1,0 \\
\hline México & 80 & 0,9 & 1,4 & 1,2 & 1,6 \\
\hline Outros & 397 & 24,3 & 17,5 & 10,2 & 8,1 \\
\hline $\begin{array}{l}\text { América do Norte + } \\
\text { Europa Ocidental + } \\
\text { Japão }\end{array}$ & 3411 & 61,1 & 65,2 & 72,2 & 69,8 \\
\hline
\end{tabular}

(1) FOB.

(2) Exclui reexportações de Hong-Kong.

(..) Dados não disponíveis.

Fonte: World Trade Organization, Annual report, 1996,v. II. 
Tabela 5

Importações de mercadorias $^{(1)}$, por regiões e países

(Em U\$ bilhões e em \%)

\begin{tabular}{lr|rrrr}
\hline & Valor & \multicolumn{4}{|c}{ Participação } \\
& 1995 & 1980 & 1985 & 1990 & 1995 \\
\hline Mundo $^{(2)}$ & 5025 & 100,0 & 100,0 & 100,0 & 100,0 \\
América do Norte & 941 & 15,5 & 21,7 & 18,4 & 18,7 \\
EUA & 771 & 12,4 & 17,7 & 14,8 & 15,3 \\
Europa Ocidental & 2186 & 44,8 & 39,9 & 48,8 & 43,5 \\
Ásia ${ }^{(2)}$ & 1258 & 16,7 & 18,8 & 20,3 & 25,0 \\
Japão & 336 & 6,8 & 6,5 & 6,8 & 6,7 \\
China & 132 & 1,0 & 2,1 & 1,5 & 2,6 \\
América Latina & 245 & 5,9 & 4,2 & 3,6 & 4,9 \\
Brasil & 54 & $(.)$. & 0,7 & 0,7 & 1,1 \\
México & 73 & 1,0 & 0,9 & 1,2 & 1,5 \\
Outros & 395 & 17,1 & 15,4 & 8,9 & 7,9 \\
\hline América do Norte + & & & & & \\
Europa Ocidental + & & & & & \\
Japão & 3463 & 67,1 & 68,1 & 74,0 & 68,9 \\
\hline
\end{tabular}

(1) CIF.

(2) Exclui importações de Hong-Kong para reexportação.

(..) Dados não disponíveis.

Fonte: World Trade Organization, Annual report, 1996, v. II. 
Tabela 6

Exportações de serviços comerciais ${ }^{(1)}$, por regiões e países selecionados

(Em U\$ bilhões e em \%)

\begin{tabular}{lr|rrr}
\hline & Valor & \multicolumn{3}{|c}{ Participação } \\
\hline & 1994 & 1985 & 1990 & 1994 \\
\hline Mundo & 1035 & 100,0 & 100,0 & 100,0 \\
América do Norte & 197 & 19,0 & 19,1 & 19,0 \\
EUA & 178 & 16,7 & 17,3 & 17,2 \\
Europa Ocidental & 509 & 50,8 & 53,7 & 49,1 \\
Ásia & 220 & 16,1 & 16,7 & 21,2 \\
Japão & 57 & 5,4 & 5,2 & 5,5 \\
América Latina & 39 & 4,7 & 3,7 & 3,8 \\
México & 9 & 1,2 & 0,9 & 0,8 \\
Brasil & 5 & 0,5 & 0,5 & 0,5 \\
Outros & 70 & 9,4 & 6,8 & 6,9 \\
\hline América do Norte + & & & & \\
Europa Ocidental + & & & & \\
Japão & 763 & 75,2 & 78,0 & 73,6 \\
\hline
\end{tabular}

(1) Inclui transportes, viagens internacionais, seguros e outros serviços comerciais. Exclui serviços governamentais.

Fonte: World Trade Organization, Annual report, 1996, Volume II. 
Tabela 7

Importações de serviços comerciais ${ }^{(1)}$, por regiões e paíises selecionados

(Em U\$ bilhões e em \%)

\begin{tabular}{lr|rrr}
\hline & Valor & \multicolumn{3}{|c}{ Participação } \\
\hline & 1994 & 1985 & 1990 & 1994 \\
\hline Mundo & 1045 & 100,0 & 100,0 & 100,0 \\
América do Norte & 153 & 17,3 & 14,8 & 14,6 \\
EUA & 125 & 14,2 & 11,9 & 11,9 \\
Europa Ocidental & 479 & 41,1 & 48,8 & 45,7 \\
Ásia & 266 & 20,3 & 22,1 & 25,4 \\
Japão & 105 & 8,6 & 10,6 & 10,1 \\
América Latina & 49 & 5,5 & 4,2 & 4,7 \\
México & 13 & 1,3 & 1,2 & 1,2 \\
Brasil & 10 & 0,8 & 0,8 & 0,9 \\
Outros & 98 & 15,8 & 10,1 & 9,6 \\
América do Norte + & & & & \\
Europa Ocidental + & & & & \\
Japão & 737 & 67,0 & 74,2 & 70,4 \\
& & & & \\
\hline
\end{tabular}

(1) Inclui transportes, viagens internacionais, seguros e outros serviços comerciais. Exclui serviços governamentais.

Fonte: World Trade Organization, Annual report, 1996, Volume II.

A concentração dos fluxos financeiros não se manifesta apenas na reduzida participação dos países em desenvolvimento. No que se refere ao mercado cambial, por exemplo, os três principais centros - Londres, Nova York e Tóquio - respondiam por $56 \%$ das transações totais em abril de 1995, segundo o Bank for International Settlements (BIS) (45). Nos mercados de títulos, o aumento da importância dos investidores institucionais - fundos de pensão, companhias de seguro, fundos mútuos e de hedgetem tido como conseqüência o predomínio de um número relativamente pequeno de grandes investidores (46). De acordo com documento do FMI, essa maior concentração de riqueza nas mãos de administradores profissionais de fundos aumenta as possibilidades de "manipulação de mercado", o que pode ser "especialmente importante em mercados menores, notadamente nos mercados emergentes" (47).

45 Id., p. 120-121.

46 International Monetary Fund, 1995, p. 165-166.

47 Id., p. 167. 
A concentração também aparece claramente nos dados referentes à distribuição geográfica dos investimentos diretos. As seis principais economias desenvolvidas destinam parte preponderante dos seus investimentos a países membros da OCDE. Nos casos dos EUA e do Japão, cerca de $70 \%$ do estoque de investimentos diretos no exterior ficam dentro da OCDE. Para as principais economias européias, a proporção é ainda maior, situando-se sempre acima de $80 \%$ e alcançando quase $90 \%$ no caso da Alemanha (tabela 8).

Tabela 8

Distribuição geográfica dos estoques de investimento direto no exterior de países desenvolvidos selecionados, 1994

(Em \% do total)

\begin{tabular}{|c|c|c|c|c|}
\hline Origem Destino & $\begin{array}{c}\text { Países da } \\
\text { OCDE }\end{array}$ & $\begin{array}{l}\text { Sudeste } \\
\text { Asiático }^{(1)}\end{array}$ & $\begin{array}{c}\text { Europa Central } \\
\text { e Oriental }^{(2)}\end{array}$ & $\begin{array}{c}\text { Outros } \\
\text { Países }\end{array}$ \\
\hline EUA & 73,5 & 7,6 & 0,4 & 18,5 \\
\hline Japão & 69,0 & 16,2 & 0,2 & 14,6 \\
\hline Alemanha & 87,8 & 2,6 & 2,1 & 7,4 \\
\hline França & 85,3 & 2,0 & 0,4 & 12,4 \\
\hline Itália & 85,8 & 0,7 & 0,9 & 12,7 \\
\hline Reino Unido & 80,1 & 6,9 & 0,2 & 12,7 \\
\hline
\end{tabular}

(1) China, Cingapura, Coréia, Filipinas, Hong Kong, Índia, Indonésia, Malásia, Tailândia e Taiwan.

(2) Bulgária, Eslováquia, Hungria, Polônia, República Tcheca, Romênia e ex-URSS.

Fonte: Organisation for Economic Co-operation and Development, OECD economic outlook, December 1996.

Além disso, uma proporção bastante elevada do estoque mundial de investimentos diretos é de propriedade de um número pequeno de grandes firmas com matrizes sediadas nos países desenvolvidos. As 100 maiores empresas internacionais não-financeiras, todas elas baseadas em países desenvolvidos, detêm nada menos que um terço do estoque global de investimento direto estrangeiro (48). Avaliado em cerca de US\$2,7 trilhões em 1995, esse estoque pertence a 38.747 empresas matrizes e suas 265.551 filiais no exterior. Aproximadamente $90 \%$ dessas matrizes estão localizadas em países desenvolvidos (49).

48 United Nations Conference on Trade and Development, 1996, p. xv. A Unctad ordena as empresas pelo valor dos ativos mantidos fora do país de origem (Id., p. 30-32).

49 Id., p. 7-9. 
Na primeira metade da década de 90 , houve aumento da participação dos países em desenvolvimento nos fluxos internacionais de investimento direto, que passaram a ser, nesse período, uma das principais fontes de ingresso de capital externo para esse conjunto de países (50). A parcela dos investimentos destinada a países em desenvolvimento, que foi da ordem de 19,2\% do total mundial em 1984-89 aumentou de forma significativa nos anos mais recentes, tendo alcançado $38,5 \% \mathrm{em}$ 1994 e 31,7\% em 1995. Também aumentou substancialmente o peso dos países em desenvolvimento como investidores no exterior (tabela 9).

Não obstante, as economias desenvolvidas ainda são largamente predominantes, respondendo por $64,5 \%$ dos fluxos de investimento recebidos do exterior e $85,1 \%$ dos fluxos de investimento realizados no exterior em 1995 (tabela 9). Os cinco principais países investidores - EUA, Alemanha, Reino Unido, Japão e França, nessa ordem - responderam por dois terços do fluxo global de investimento no exterior em 1995 (51). Em termos de estoques, a Unctad estima que as economias desenvolvidas respondiam, em 1995, por $72,7 \%$ dos investimentos diretos recebidos do exterior e por $92,1 \%$ dos investimentos realizados no exterior (52).

Antes da Primeira Guerra Mundial, a distribuição dos investimentos diretos era aparentemente menos desigual (53). Os EUA eram o principal receptor de investimentos estrangeiros, mas países em desenvolvimento na América Latina, na Ásia e em regiões menos industrializadas da Europa também recebiam fluxos substanciais. Em 1914, a maior parte do estoque de investimentos diretos estava concentrada em países hoje considerados em desenvolvimento, notadamente na América Latina (54). A Ásia, a África, a América Latina e a Oceania respondiam por $66,2 \%$ do investimento direto estrangeiro em 1913, em comparação com uma participação de 17,7\% da Europa e 16\% da América do Norte. Só a América Latina respondia por 32,7\% do total (55). Também desse ponto de vista, a economia do início do século parece ter sido mais "globalizada" do que a atual.

50 International Monetary Fund, 1997b, p. 43.

51 United Nations Conference on Trade and Development, 1996, p.4.

52 Id., Annex table 3, p. 239; Annex table 4, p. 245.

53 Nayyar, 1995, p. 14.

54 United Nations Conference on Trade and Development, 1994, p. 121, 159. Dentro da América Latina, entretanto, a distribuição dos fluxos de capital era muito desigual. Nos anos 80 do século passado, apenas dois países - a Argentina e o Uruguai - responderam por $60 \%$ do valor dos empréstimos negociados pela região (Bairoch \& Kozul-Wright, 1996, p. 12).

55 Id., Ibid.. Nessa época, contudo, o PIB per capita era mais alto na Argentina do que em alguns dos principais países da Europa Ocidental e países como o Chile e o México tinham um nível de desenvolvimento comparável ao de algumas economias da periferia européia (United Nations Conference on Trade and Development, 1994, p. 159). 
Tabela 9

Fluxos de investimento direto estrangeiro

\begin{tabular}{|c|c|c|c|c|c|c|c|c|c|c|}
\hline \multirow[t]{2}{*}{ Ano } & \multicolumn{2}{|c|}{ Países Desenvolvidos } & \multicolumn{2}{|c|}{$\begin{array}{c}\text { Países em } \\
\text { Desenvolvimento }\end{array}$} & \multicolumn{2}{|c|}{$\begin{array}{c}\text { Países em } \\
\text { Desenvolvimento } \\
\text { Exclusive China }\end{array}$} & \multicolumn{2}{|c|}{$\begin{array}{c}\text { Europa Central } \\
\text { e Oriental }\end{array}$} & \multicolumn{2}{|c|}{ Todos os Países } \\
\hline & Ingressos & Saídas & Ingressos & Saídas & Ingressos & Saídas & Ingressos & Saídas & Ingressos & Saídas \\
\hline \multicolumn{11}{|c|}{ (Valores em U\$ bilhões) } \\
\hline $1984-1989^{(1)}$ & 93,1 & 114,0 & 22,2 & 7,6 & 19,9 & 7,0 & 0,0 & $(-)$ & 115,4 & 121,6 \\
\hline 1990 & 169,8 & 222,5 & 33,7 & 17,8 & 30,2 & 16,9 & 0,3 & $(-)$ & 203,8 & 240,3 \\
\hline 1991 & 114,0 & 201,9 & 41,3 & 8,9 & 37,0 & 7,9 & 2,5 & $(-)$ & 157,8 & 210,8 \\
\hline 1992 & 114,0 & 181,4 & 50,4 & 21,6 & 39,2 & 17,6 & 3,7 & 0,1 & 168,1 & 203,1 \\
\hline 1993 & 129,3 & 192,4 & 73,1 & 33,0 & 45,6 & 28,6 & 5,5 & 0,2 & 207,9 & 225,5 \\
\hline 1994 & 132,8 & 190,9 & 87,0 & 38,6 & 53,2 & 36,6 & 5,9 & 0,6 & 225,7 & 230,0 \\
\hline $1995^{(2)}$ & 203,2 & 270,5 & 99,7 & 47,0 & 62,2 & 43,5 & 12,1 & 0,3 & 314,9 & 317,8 \\
\hline \multicolumn{11}{|c|}{ (Participação no total em \%) } \\
\hline $1984-1989^{(1)}$ & 80,7 & 93,8 & 19,2 & 6,3 & 17,2 & 5,8 & 0,0 & $(-)$ & 100,0 & 100,0 \\
\hline 1990 & 83,3 & 92,6 & 16,5 & 7,4 & 14,8 & 7,0 & 0,1 & $(-)$ & 100,0 & 100,0 \\
\hline 1991 & 72,2 & 95,8 & 26,2 & 4,2 & 23,4 & 3,7 & 1,6 & $(-)$ & 100,0 & 100,0 \\
\hline 1992 & 67,8 & 89,3 & 30,0 & 10,6 & 23,3 & 8,7 & 2,2 & $(-)$ & 100,0 & 100,0 \\
\hline 1993 & 62,2 & 85,3 & 35,2 & 14,6 & 21,9 & 12,7 & 2,6 & 0,0 & 100,0 & 100,0 \\
\hline 1994 & 58,8 & 83,0 & 38,5 & 16,8 & 23,6 & 15,9 & 2,6 & 0,3 & 100,0 & 100,0 \\
\hline $1995^{(2)}$ & 64,5 & 85,1 & 31,7 & 14,8 & 19,8 & 13,7 & 3,8 & 0,1 & 100,0 & 100,0 \\
\hline
\end{tabular}

(1) Média anual.

(2) Dados estimados.

(-) Dados iguais a ou próximos de zero.

Fonte: United Nations Conference on Trade and Development, World investment report, 1996. 
A concentração das atividades econômicas internacionais no final do século XX aparece, também, quando se considera a distribuição da parte que cabe aos países mais atrasados. Como nota Rogalski, a "globalização" opera uma verdadeira fratura entre uma dezena de países em desenvolvimento, que são admitidos nos mercados internacionais de capitais, e todos os demais (56). Nos anos 90, tem sido muito elevado o grau de concentração dos investimentos diretos realizados nos países em desenvolvimento. Apenas dez países responderam por nada menos que 77,3\% do total dos investimentos recebidos por 147 países em desenvolvimento em 1995. Os cinco principais países - China, México, Malásia, Cingapura e Brasil, nessa ordem - receberam $60,6 \%$ do total. Só a China respondeu por 37,6\%. Na outra ponta, os 48 países menos desenvolvidos receberam, em 1995, apenas US\$ 1,1 bilhão sob a forma de investimento direto estrangeiro, $1,1 \%$ do total recebido pelo conjunto dos países em desenvolvimento (57). Note-se, finalmente, que excluída a China, a participação dos países em desenvolvimento no total mundial de ingressos de investimento direto cresceu de forma modesta na primeira metade dos anos 90 em comparação com o registrado em 1984-89 (tabela 9).

Diante desses dados, há quem prefira referir-se a "globalização excludente" ou "globalização concentradora", oxímoros verbais que só contribuem para aumentar a confusão reinante na caracterização do quadro internacional. Não é evidente que a expressão "globalização" perde sentido quando não se refere a um processo includente? Mas se "globalização includente" é um pleonasmo, "globalização excludente" só pode ser uma contradição em termos.

\section{O mito do declínio do Estado}

A ideologia da "globalização" é especialmente enganosa quando associada à idéia de que está em curso na economia mundial um declínio do Estado e das suas possibilidades de intervenção nos domínios econômico e social. Não por acaso, essa associação é muito comum. Na origem, a ideologia da "globalização" é um desdobramento do "neoliberalismo" e está impregnada de Estadofobia. A celebração das virtudes ecumênicas da competição e do mercado livre constitui um dos seus aspectos centrais.

No plano doutrinário, os últimos 20 ou 25 anos têm sido marcados por um movimento regressivo, de restauração do ideário econômico do século XIX, e pelo predomínio de uma vertente do pensamento econômico que reserva ao Estado um campo bastante limitado de funções. De acordo com essa concepção, que representa um virtual retorno ao État gendarme pregado pelos liberais do século passado, o Estado deveria atuar fundamentalmente na definição e proteção dos direitos de pro-

56 Rogalski, 1997, p. 10.

57 United Nations Conference on Trade and Development, Annex table 5, p. 227-231. 
priedade e do sistema de leis e contratos, na garantia da segurança interna e externa do país e na defesa da estabilidade do padrão monetário. Para além disso, os governos deveriam, no máximo, proporcionar educação básica, uma rede mínima de proteção social e alguns investimentos de infra-estrutura (Barro, 1996:xiii).

A rigor, não haveria porque designar essa corrente de "neoliberal". A etiqueta confere status de novidade a um fenômeno ideológico que representa uma volta ao passado e não incorpora nada de fundamentalmente novo ao velho liberalismo. Como há um preconceito generalizado a favor do novo e do "progresso", o prefixo "neo" coloca os seus adversários, de saída, em posição desvantajosa. É uma concessão indevida, que enfraquece automaticamente a crítica. Mais apropriado seria falar em "paleoliberalismo".

Seja como for, mais importante do que questionar o rótulo é notar que o "neoliberalismo", apesar do seu aparente triunfo, tem pouca correspondência com a atuação concreta do Estado nos países desenvolvidos. Há uma enorme distância entre a retórica "neoliberal" e a realidade prática dos países nos quais essa ideologia teve origem. Como grande parte da discussão, inclusive nos meios acadêmicos, se dá em nível puramente doutrinário, essa distância não tem recebido a devida atenção.

Robert Barro, um dos principais discípulos de Milton Friedman e um dos mais respeitados economistas norte-americanos da atualidade, observa que as propostas de política econômica e social apresentadas por Friedman estão fundadas na filosofia liberal do século passado e têm recebido "séria atenção nos Estados Unidos e em outros países" (58). Atenção, sim; aplicação, nem tanto. Nos países desenvolvidos, o prestígio intelectual e acadêmico dos teóricos e ideólogos do "neoliberalismo" contrasta de forma notável com a sua limitada influência prática, especialmente nos anos mais recentes.

Como se sabe, o "neoliberalismo" representou uma reação ao predomínio do keynesianismo e de variantes da social-democracia nos países desenvolvidos nas décadas que se seguiram à Segunda Guerra Mundial. Nesse período, tomou corpo uma visão abrangente das funções alocativas, estabilizadoras e distributivas que deveriam ser desempenhadas por um governo moderno. Isso contribuiu para legitimar o rápi-

58 Barro, 1996, p. xiv. A lista de propostas de Friedman inclui livre escolha de escolas, alíquota única para o imposto de renda, regras para a estabilidade monetária, privatização da seguridade social e eliminação de diversos programas sociais (Id., Ibid.). Pouco ou nada dessas propostas tem sido aplicado nos principais países desenvolvidos. Em entrevista recente a uma revista brasileira, o próprio Friedman lamentou certas tendências da política econômica nos EUA: "Infelizmente, a política econômica de Clinton não tem sido nada mais do que a continuação da política econômica de Bush. Ambos aumentaram o grau de regulamentação da economia. Do mesmo modo, ambos aumentaram o controle sobre a vida das pessoas nos Estados Unidos, bem como as alíquotas marginais de imposto, que incidem sobre a renda adicional" (Entrevista: Um Crítico Contumaz", Revista Bovespa, janeiro de 1996, p. 6). 
do crescimento da presença do Estado na economia desses países, dando prosseguimento a uma tendência que remontava à Primeira Guerra Mundial (59).

Contra essa tendência, insurgiram-se pensadores como Hayek e Friedman que, inicialmente sem muito sucesso, alertaram incessamente para os riscos econômicos e políticos da crescente intervenção do Estado e pregaram uma restauração do ideário pré-keynesiano. Com a aceleração da inflação desde fins dos anos 60 e especialmente com a estagflação de meados dos anos 70 , os "neoliberais" conseguiram finalmente ampliar a sua influência nos meios acadêmicos e no debate público, colocando seus adversários keynesianos e social-democratas na defensiva. Cresceram o ceticismo quanto à eficácia da ação do Estado e a insatisfação com o peso crescente da carga tributária. Foi neste contexto que chegaram ao poder líderes políticos como Margaret Thatcher na Inglaterra e Ronald Reagan nos EUA. Rompendo com a tradição conciliatória das alas moderadas dos seus partidos, Thatcher e Reagan partiram para um ataque determinado e sistemático à intervenção econômica do Estado.

No entanto, ao contrário do que geralmente se imagina, essa ofensiva "neoliberal" ou "paleoliberal" - e esse é o ponto que cabe destacar neste contexto não chegou a modificar de forma substancial e duradoura a dimensão do Estado na grande maioria dos países desenvolvidos. Como veremos, nem mesmo interrompeu a tendência de aumento do peso do governo, medido por indicadores agregados como a relação entre a despesa e a receita públicas e o PIB. Como notam Tanzi e Schuknecht, "poucos países acompanharam a sua retórica anti-governo com mudanças efetivas nos seus regimes de política econômica" (60).

De uma forma geral, esse ponto não tem sido suficientemente registrado no debate brasileiro, o que talvez possa ser parcialmente atribuído à introversão característica de países de porte continental. Poucos procuram verificar o que de fato está acontecendo no mundo e as controvérsias adquirem, muitas vezes, um caráter artifical e até surrealista. Indiferentes à realidade internacional, os porta-vozes brasileiros do "neoliberalismo" e da "globalização" pregam a aplicação de modelos que são pouco aplicados nos países onde têm origem essas ideologias. Enquanto isso, os seus adversários ideológicos investem contra moinhos de vento, ou se deixam intimidar pelo discurso dominante.

Nesse debate, o papel da maioria dos economistas tem sido o de propagar servilmente o ideário dominante. Suscetíveis ao prestígio das "teorias" consagradas

59 Tanzi \& Schuknecht, 1995, p. 5-6. Nos países do G-7, a participação do gasto estatal no PIB passou de uma média simples de $11 \%$ em 1913 para 19,5\% em 1920, 25,5\% em 1937 e $28,9 \%$ em 1960 (Id., p. 4).

60 Id., p. 7. Nos países em desenvolvimento, ao contrário, o período recente marca a reversão da tendência de aumento da participação do Estado na economia. Para o conjunto desses países, a relação entre os gastos do governo central e o PIB, que vinha aumentando de forma expressiva desde 1960, diminuiu a partir de meados da década de 80 (The World Bank, 1997, p. 2, 22). 
pelos interesses e preconceitos predominantes, prestam-se geralmente a repetir chavões e frases feitas a respeito da "nova ordem" a que o Brasil tem de se adaptar para "não ficar à margem do mundo". Mutatis mutandis, aplica-se a eles o que dizia Schopenhauer dos filósofos do seu tempo: submetidos à regra do primum vivere, estão sempre dispostos, e com o mais solene desprezo por realidades inconvenientes, a deduzir a priori absolutamente tudo o que lhes for pedido, o bom Deus, o diabo ou o que seja (61).

Em conseqüência da alienação reinante, prevalece no Brasil a conviç̧ão de que a tendência mundial é de redução do papel do Estado no campo econômico e social. E como disse Nietzsche, a conviç̧ão é mais perigosa para a verdade do que a mentira (Nietzsche, 1878:693). É verdade que em certas regiões do mundo, em grande parte da África e da América Latina, por exemplo, o Estado entrou em fase de declínio ou até de desmantelamento (62). Mas não é o que vem acontecendo nos países desenvolvidos ou nos países em desenvolvimento mais bem-sucedidos.

Esse desconhecimento de aspectos centrais da evolução da economia internacional acaba tendo efeitos práticos. Nos últimos anos, particularmente desde o governo Collor, a política econômica nacional vem se caracterizando, em larga medida, como uma adaptação passiva não às tendências mundiais, tal como realmente ocorrem, mas a uma versão mitificada, construída para consumo na periferia subdesenvolvida.

E, no entanto, não é necessário grande esforço para perceber as falácias do discurso hegemônico. Basta consultar, por exemplo, as estatísticas publicadas por organizações internacionais como a OCDE e o FMI. Quem se der ao trabalho de fazê-lo, verá que nos anos 80 e na primeira metade dos anos 90, em plena época de suposto triunfo do chamado "neoliberalismo", a participação do Estado na economia não diminuiu nos países mais adiantados. Ao contrário, aumentou em quase todos eles.

É certo que houve desregulamentação de mercados, remoção de barreiras ao comércio internacional, acordos multilaterais e regionais de liberalização comercial, eliminação de controles sobre os movimentos internacionais de capital e programas importantes de privatização de empresas públicas. Mas a participação do Estado na economia, que já vinha crescendo de forma expressiva e contínua desde a Primeira Guerra Mundial, continuou a aumentar no período mais recente, a despeito da preponderância ideológica do pensamento "neoliberal".

61 Citado em Roger, 1995, p. XVI.

62 No seu último relatório anual sobre o desenvolvimento mundial, até o Banco Mundial criticou a exagerada rejeição do Estado observada em muitos países em desenvolvimento nos anos 80. Na África, na antiga União Soviética e em partes da América Latina, essa rejeição contribuiu para o "abandono das funções vitais do Estado, ameaçando o bemestar social e erodindo os fundamentos do desenvolvimento do mercado" (The World Bank, 1997, p. 24-25). Na América Latina, a participação do gastos do governo central no PIB diminuiu de forma acentuada entre 1980-84 e 1990-94 (Id., p. 22). 
Convém comparar os indicadores agregados do final dos anos 70 e início dos anos 80 com os do período mais recente. Essa comparação permite avaliar a evolução da participação do Estado nas economias desenvolvidas no período que se seguiu à tentativa de restauração liberal inaugarada com a chegada de Thatcher e Reagan ao poder, em 1979 e 1981, respectivamente.

Observe-se, por exemplo, a relação entre o gasto público total (inclusive unidades subnacionais) e o PIB (tabelas 10 e 11 ). Nos EUA, o gasto público passou de $31,2 \%$ do PIB em 1978-82 para 33,6\% em 1991-95. No Japão, de 31,8\% para $33,2 \%$. Na Alemanha, de $48 \%$ para 48,9\%. No Grupo dos 7 (G-7), que inclui, além dos três países citados, o Canadá, a França, a Itália e o Reino Unido, a média ponderada da relação despesa pública/PIB aumentou de 36,3\% para 39,4\%. A Alemanha e o Reino Unido foram os únicos países do G-7 a registrar relativa estabilidade do gasto como proporção do PIB nesse período (tabela 10) (63).

Em um subconjunto de 19 países membros da OCDE, que respondem por mais de $90 \%$ do PIB total dos países da entidade, a relação despesa pública/PIB aumentou de 37,3\% em 1978-82 para 40,7\% em 1991-95. Em apenas três países (Bélgica, Holanda e Irlanda), observou-se diminuição dessa relação (tabela 11)(64).

Do lado da receita pública, a tendência geral também foi de aumento nesse período, a despeito da crescente insatisfação com o nível da tributação e das fortes restrições que a "globalização" da produção e dos mercados estaria supostamente impondo à capacidade tributária dos Estados nacionais. A carga tributária macroeconômica, definida como a relação entre a receita corrente do governo (inclusive governos estaduais e locais) e o PIB, aumentou na grande maioria dos países desenvolvidos em plena época de suposta hegemonia do "neoliberalismo" (tabelas 10 e 11$)$.

Nos países do G-7, a média ponderada da carga tributária cresceu de 33,5\% em 1978-82 para 35,9\% em 1991-95. No grupo, apenas o Reino Unido registrou diminuição da carga tributária nesse período, de $39,6 \%$ para $36,9 \%$. Na França, no Japão, no Canadá e sobretudo na Itália, houve aumentos expressivos da receita pública como proporção do PIB (tabela 10).

63 No Reino Unido, a razão gasto público/PIB chegou a cair de 45\% em 1983 para 37,5\% em 1989, mas voltou a subir para 42,9\% em 1994. Em 1994, as despesas com transferências e subsídios eram mais altas do que no começo das reformas realizadas pelo governo Thatcher (Tanzi \& Schuknecht, 1995, p. 30-31).

64 Entre 1980 e 1994, os componentes mais dinâmicos do gasto público nos países desenvolvidos foram os subsídios e as transferências, os juros da dívida e outras despesas (inclusive de capital). Os gastos de consumo dos governos (salários, ordenados e compras de materiais) permaneceram aproximadamente estáveis nesse período. ( $I d$., 4, 8-10, 11 , $15)$. 
Tabela 10

Setor público ${ }^{(1)}$ nos países do G-7

(Médias dos períodos em \% do PIB nominal)

\begin{tabular}{|c|c|c|c|c|c|c|c|}
\hline Países & Período & $\begin{array}{c}\text { Gasto } \\
\text { Público }^{(2)}\end{array}$ & $\begin{array}{c}\text { Carga } \\
\text { Tributária }{ }^{(3)}\end{array}$ & $\begin{array}{l}\text { Juros } \\
\text { Líquidos }\end{array}$ & $\begin{array}{l}\text { Déficit } \\
\text { Público }\end{array}$ & $\begin{array}{c}\text { Dívida } \\
\text { Pública Bruta }\end{array}$ & $\begin{array}{l}\text { Dívida Pública } \\
\text { Líquida }^{(4)}\end{array}$ \\
\hline \multirow[t]{2}{*}{$E U A$} & $1978-82$ & 31,2 & 30,1 & 1,3 & 1,1 & 37,9 & 22,3 \\
\hline & 1991-95 & 33,6 & 30,5 & 2,1 & 3,1 & 62,6 & 47,7 \\
\hline \multirow[t]{2}{*}{ Japão } & 1978-82 & 31,8 & 27,4 & 1,0 & 4,4 & 50,7 & 16,4 \\
\hline & 1991-95 & 33,2 & 32,7 & 0,3 & 0,5 & 69,5 & 6,1 \\
\hline \multirow[t]{2}{*}{ Alemanba } & $1978-82^{(5)}$ & 48,0 & 45,0 & 1,4 & 3,0 & 34,0 & 13,1 \\
\hline & 1991-95 & 48,9 & 45,7 & 2,6 & 3,1 & 51,1 & 33,5 \\
\hline \multirow[t]{2}{*}{ França } & 1978-82 & 46,9 & 45,4 & 0,9 & 1,5 & 31,5 & 0,1 \\
\hline & 1991-95 & 53,0 & 48,6 & 2,9 & 4,4 & 51,1 & 25,3 \\
\hline \multirow[t]{2}{*}{ Itália } & $1978-82$ & 44,0 & 33,7 & 4,8 & 10,4 & 61,3 & 56,8 \\
\hline & 1991-95 & 54,1 & 45,0 & 9,9 & 9,1 & 116,8 & 101,1 \\
\hline \multirow[t]{2}{*}{ Reino Unido } & 1978-82 & 42,8 & 39,6 & 3,0 & 3,2 & 54,9 & 39,9 \\
\hline & 1991-95 & 42,7 & 36,9 & 2,4 & 5,8 & 51,8 & 31,7 \\
\hline \multirow[t]{2}{*}{ Canadá } & $1978-82$ & 39,9 & 36,8 & 2,1 & 3,1 & 45,7 & 13,4 \\
\hline & 1991-95 & 48,5 & 42,4 & 5,2 & 6,1 & 91,6 & 61,1 \\
\hline \multirow[t]{2}{*}{$G^{-76)}$} & 1978-82 & 36,3 & 33,5 & 1,6 & 2,9 & 42,6 & 22,0 \\
\hline & $1991-95$ & 39,4 & 35,9 & 2,6 & 3,5 & 66,2 & 40,4 \\
\hline
\end{tabular}

(1) Inclui governos centrais, estaduais e locais.

(2) Despesas correntes mais despesas líquidas de capital.

(3) Receitas correntes. Exclui receitas de capital.

(4) Dívida bruta menos ativos financeiros.

(5) Alemanha Ocidental.

(6) Médias ponderadas com base no PIB dos sete países. Pesos utilizados: EUA - 0,4525; Japão - 0,1812; Alemanha - 0,1038; França 0,0793; Itália - 0,0743; Reino Unido - 0,0689; Canadá - 0,0400.

Fonte: Organisation for Economic Co-operation and Development, OECD economic outlook, June 1995, June 1996 \& December 1996. 
Tabela 11

Setor público ${ }^{(1)}$ em outros países da OCDE

(Médias dos períodos em \% do PIB nominal)

\begin{tabular}{|c|c|c|c|c|c|c|c|}
\hline Países & Período & $\begin{array}{c}\text { Gasto } \\
\text { Público }^{(2)}\end{array}$ & $\begin{array}{c}\text { Carga } \\
\text { Tributária }^{(3)}\end{array}$ & $\begin{array}{l}\text { Juros } \\
\text { Líquidos }\end{array}$ & $\begin{array}{l}\text { Déficit } \\
\text { Público }\end{array}$ & $\begin{array}{l}\text { Dívida } \\
\text { Pública } \\
\text { Bruta }\end{array}$ & $\begin{array}{c}\text { Dívida } \\
\text { Pública } \\
\text { Líquida }^{(4)}\end{array}$ \\
\hline Austrália & $\begin{array}{l}1978-82 \\
1991-95\end{array}$ & $\begin{array}{l}32,0 \\
37,2\end{array}$ & $\begin{array}{l}30,4 \\
33,9\end{array}$ & $\begin{array}{l}0,8 \\
1,9\end{array}$ & $\begin{array}{l}1,6 \\
3,3\end{array}$ & $\begin{array}{c}(. .) \\
33,8\end{array}$ & $\begin{array}{r}(. .) \\
21,3\end{array}$ \\
\hline Áustria & $\begin{array}{l}1978-82 \\
1991-95\end{array}$ & $\begin{array}{l}49,0 \\
51,6\end{array}$ & $\begin{array}{l}46,6 \\
47,8\end{array}$ & $\begin{array}{l}1,9 \\
3,4\end{array}$ & $\begin{array}{l}2,4 \\
3,8\end{array}$ & $\begin{array}{l}37,7 \\
62,8\end{array}$ & $\begin{array}{r}(. .) \\
43,4\end{array}$ \\
\hline Bélgica & $\begin{array}{l}1978-82 \\
1991-95\end{array}$ & $\begin{array}{l}59,7 \\
55,9\end{array}$ & $\begin{array}{l}50,4 \\
49,9\end{array}$ & $\begin{array}{l}5,9 \\
9,5\end{array}$ & $\begin{array}{l}9,4 \\
6,1\end{array}$ & $\begin{array}{r}83,0 \\
133,2\end{array}$ & $\begin{array}{r}73,7 \\
124,5\end{array}$ \\
\hline Dinamarca & $\begin{array}{l}1978-82 \\
1991-95\end{array}$ & $\begin{array}{l}56,2 \\
61,7\end{array}$ & $\begin{array}{l}51,9 \\
58,9\end{array}$ & $\begin{array}{l}1,0 \\
3,3\end{array}$ & $\begin{array}{l}4,3 \\
2,8\end{array}$ & $\begin{array}{l}43,1 \\
77,7\end{array}$ & $\begin{array}{l}15,4 \\
43,4\end{array}$ \\
\hline Espanba & $\begin{array}{l}1978-82 \\
1991-95\end{array}$ & $\begin{array}{l}32,6 \\
45,2\end{array}$ & $\begin{array}{l}29,5 \\
39,6\end{array}$ & $\begin{array}{l}0,3 \\
4,5\end{array}$ & $\begin{array}{l}3,0 \\
5,6\end{array}$ & $\begin{array}{l}20,7 \\
60,6\end{array}$ & $\begin{array}{r}7,5 \\
41,0\end{array}$ \\
\hline Finlândia & $\begin{array}{l}1978-82 \\
1991-95\end{array}$ & $\begin{array}{l}39,2 \\
58,2\end{array}$ & $\begin{array}{l}42,3 \\
52,8\end{array}$ & $\begin{array}{l}-1,0 \\
-0,5\end{array}$ & $\begin{array}{r}-3,1 \\
5,4\end{array}$ & $\begin{array}{l}14,3 \\
51,1\end{array}$ & $\begin{array}{l}-29,4 \\
-20,1\end{array}$ \\
\hline Grécia & $\begin{array}{l}1978-82 \\
1991-95\end{array}$ & $\begin{array}{l}31,8 \\
46,7\end{array}$ & $\begin{array}{l}27,5 \\
34,9\end{array}$ & $\begin{array}{r}2,3 \\
12,2\end{array}$ & $\begin{array}{r}4,3 \\
11,8\end{array}$ & $\begin{array}{r}25,4 \\
105,1\end{array}$ & $\begin{array}{l}(. .) \\
(. .)\end{array}$ \\
\hline Holanda & $\begin{array}{l}1978-82 \\
1991-95\end{array}$ & $\begin{array}{l}55,7 \\
54,1\end{array}$ & $\begin{array}{l}51,4 \\
50,6\end{array}$ & $\begin{array}{l}2,6 \\
4,8\end{array}$ & $\begin{array}{l}4,4 \\
3,6\end{array}$ & $\begin{array}{l}47,7 \\
79,3\end{array}$ & $\begin{array}{l}24,7 \\
41,9\end{array}$ \\
\hline Irlanda & $\begin{array}{l}1978-82 \\
1991-95\end{array}$ & $\begin{array}{l}48,3 \\
42,3\end{array}$ & $\begin{array}{l}36,6 \\
40,0\end{array}$ & $\begin{array}{l}3,9 \\
4,7\end{array}$ & $\begin{array}{r}11,7 \\
2,3\end{array}$ & $\begin{array}{l}73,0 \\
92,6\end{array}$ & $\begin{array}{l}(. .) \\
(. .)\end{array}$ \\
\hline Islândia & $\begin{array}{l}1978-82 \\
1991-95\end{array}$ & $\begin{array}{c}(. .) \\
40,0\end{array}$ & $\begin{array}{r}(. .) \\
36,4\end{array}$ & $\begin{array}{l}(. .) \\
2,1\end{array}$ & $\begin{array}{l}(. .) \\
3,6\end{array}$ & $\begin{array}{r}(. .) \\
47,6\end{array}$ & $\begin{array}{r}(. .) \\
28,2\end{array}$ \\
\hline Noruega & $\begin{array}{l}1978-82 \\
1991-95\end{array}$ & $\begin{array}{l}45,1 \\
50,0\end{array}$ & $\begin{array}{l}48,0 \\
50,1\end{array}$ & $\begin{array}{l}-0,1 \\
-0,5\end{array}$ & $\begin{array}{l}-2,9 \\
-0,1\end{array}$ & $\begin{array}{l}49,3 \\
37,6\end{array}$ & $\begin{array}{r}1,9 \\
-27,3\end{array}$ \\
\hline Portugal & $\begin{array}{l}1978-82 \\
1991-95\end{array}$ & $\begin{array}{l}35,4 \\
43,4\end{array}$ & $\begin{array}{l}30,2 \\
38,0\end{array}$ & $\begin{array}{l}3,5 \\
6,9\end{array}$ & $\begin{array}{l}5,2 \\
5,4\end{array}$ & $\begin{array}{l}35,0 \\
68,2\end{array}$ & $\begin{array}{l}(. .) \\
(. .)\end{array}$ \\
\hline Suécia & $\begin{array}{l}1978-82 \\
1991-95\end{array}$ & $\begin{array}{l}61,2 \\
66,8\end{array}$ & $\begin{array}{l}57,3 \\
58,9\end{array}$ & $\begin{array}{r}-0,2 \\
1,2\end{array}$ & $\begin{array}{l}3,9 \\
7,9\end{array}$ & $\begin{array}{l}46,4 \\
72,5\end{array}$ & $\begin{array}{r}-12,1 \\
12,0\end{array}$ \\
\hline$O C D E^{(5)}$ & $\begin{array}{l}1978-82^{(6)} \\
1991-95\end{array}$ & $\begin{array}{l}37,3 \\
40,7\end{array}$ & $\begin{array}{l}34,3 \\
37,0\end{array}$ & $\begin{array}{l}1,6 \\
2,9\end{array}$ & $\begin{array}{l}2,9 \\
3,7\end{array}$ & $\begin{array}{l}42,0^{(7)} \\
66,6\end{array}$ & $\begin{array}{l}21,4^{(8)} \\
40,1^{(9)}\end{array}$ \\
\hline
\end{tabular}

(1) Inclui governos centrais, estaduais e locais; (2) Despesas correntes mais despesas líquidas de capital; (3) Receitas correntes. Exclui receitas de capital; (4) Dívida bruta menos ativos financeiros; (5) Subconjunto dos países membros da OCDE. Inclui países do G-7 e Austrália, Áustria, Bélgica, Dinamarca, Espanha, Finlândia, Grécia, Holanda, Irlanda, Islândia, Noruega, Portugal e Suécia. Média ponderada com base no PIB desses 20 países, que respondem por $92,4 \%$ do PIB total da OCDE; (6) Exclui Islândia; (7) Exclui Austrália; (8) Exclui Austrália, Áustria, Grécia, Irlanda e Portugal; (9) Exclui Grécia, Irlanda e Portugal; (..) Dados não disponíveis.

Fonte: Organisation for Economic Co-operation and Development, OECD economic outlook, June 1995, June 1996 \& December 1996. 
No já referido subconjunto de 19 países membros da OCDE, a carga tributária média aumentou de 34,3\% em 1978-82 para 37\% em 1991-95. Nesse período, além do Reino Unido, só a Bélgica e a Holanda tiveram diminuição, porém pouco significativa, da carga tributária (tabela 11).

Relatório recente do FMI atribui o aumento da carga tributária, observado "em quase todos os países desenvolvidos nas últimas duas décadas", ao aumento das contribuições sociais e a "impostos diretos mais altos - muitas vezes via alíquotas marginais elevadas" (65). Dados apresentados no estudo já citado de Tanzi e Schuknecht mostram que os impostos indiretos permaneceram praticamente estáveis como proporção do PIB, enquanto os impostos diretos e as contribuições sociais aumentaram de modo expressivo nos países desenvolvidos desde 1970 (66).

No entanto, como o aumento das receitas não acompanhou a expansão do gastos, o déficit público aumentou como proporção do PIB na maioria países desenvolvidos (tabelas 10 e 11). No G-7, o déficit médio cresceu de 2,9\% do PIB em 1978-82 para 3,5\% em 1991-95 (tabela 10), apesar da importância atribuída ao ajuste das contas públicas pela retórica "neoliberal”. Isso não impediu, diga-se de passagem, que esses países realizassem grande progresso em matéria de combate à inflação (67).

No mesmo período, o endividamento do setor público cresceu de forma ainda mais acentuada. Nos países do G-7, a dívida pública bruta subiu de uma média de 42,6\% do PIB em 1978-82 para 66,2\% em 1991-95. Em termos líquidos, o endividamento governamental quase dobrou nesse período, passando de $22 \%$ para 40,4\% do PIB, em média (tabela 10). Num subconjunto de 14 países da OCDE para os quais há dados, apenas o Japão, o Reino Unido e a Noruega registraram queda da relação dívida líquida/PIB nesse período (tabelas 10 e 11) (68).

No plano da política de comércio exterior, também é notável a distância entre retórica e realidade. Enquanto as barreiras comerciais vêm descendo no Sul, o movi-

65 International Monetary Fund, 1996a, p. 45.

66 Em um grupo de 17 países desenvolvidos (que inclui os do G-7, mais 8 países europeus, a Austrália e a Nova Zelândia), a média simples da relação impostos indiretos/PIB foi $11,1 \%$ em 1970 e $11,8 \%$ em 1990. Os impostos diretos aumentaram de $11,5 \%$ do PIB em 1970 para $15,2 \%$ em 1990 , em média. As contribuições sociais, de $6,8 \%$ para $11 \%$ do PIB (Tanzi \& Schuknecht, 1995, p. 16).

67 Entre 1978-82 e 1991-95, a taxa anual média de inflação, medida por índices de preços ao consumidor, caiu de 9\% para 3\% nos países do G-7 (Organisation for Economic Cooperation and Development, dez. 1996, p. A19).

68 Levantamento apresentado em relatório já citado do FMI, embora com diferenças em relação aos números da OCDE, mostra tendência semelhante para o endividamento líquido do setor público nos países desenvolvidos. Para um conjunto de 15 países desenvolvidos, incluindo os do G-7 e mais 8 países da Europa, os dados do FMI registram aumento da dívida pública líquida como proporção do PIB em 12 países entre 1978-80 e 1995. Apenas Japão, Noruega e Reino Unido tiveram redução na razão dívida líquida/ PIB nesse período (International Monetary Fund, 1996a, p. 51). 
mento no Norte tem sido na direção oposta. Nos países desenvolvidos, as tarifas diminuíram, em geral no contexto de acordos regionais ou multilaterais de liberalização comercial, mas foram substituídas por amplo espectro de medidas não-tarifárias de controle das importações. Nos anos 80 , das 24 economias que então integravam a OCDE, apenas quatro (Japão, Austrália, Nova Zelândia e Turquia) reduziram obstáculos ao comércio, sendo que essas eram as que tinham as barreiras mais altas no início do período (Wade, 1996:69). O Japão, que participou com relutância das sucessivas rodadas multilaterais de liberalização, continua mantendo pesadas restrições às importações. Segundo estimativa recente, essas barreiras reduzem em pelo menos US\$ 50 bilhões as suas importações anuais (Bergsten, 1996:9-10).

Mesmo no setor financeiro, área em que mais avançou o processo de internacionalização, o papel do Estado continua crucial. O funcionamento dos mercados financeiros domésticos e internacionais continua dependendo decisivamente da atuação dos Estados nacionais no campo regulatório ou como emprestadores de última instância em momentos de crise financeira. No clássico dilema entre moral hazard e risco de contágio e colapso financeiro, a preocupação com o segundo aspecto quase sempre prevalece na prática. Recorde-se, por exemplo, a mega-intervenção comandada pelo governo dos EUA por ocasião do pânico financeiro mexicano em fins de 1994 e início de 1995. Secundado pelo FMI, o Estado nacional dos EUA, velho de guerra, veio em socorro dos mercados financeiros "transnacionais" e especialmente dos investidores norte-americanos, mobilizando empréstimos de dezenas de bilhões de dólares para o México. A rápida intervenção do governo norte-americano impediu que o governo mexicano entrasse em moratória e conteve, assim, a propagação da crise, cujos efeitos mais graves ficaram restritos basicamente ao próprio México e à Argentina (Batista Jr., 1996:157-158).

Em suma, o "neoliberalismo" reina, mas não governa. As homenagens prestadas a essa ideologia contrastam com a sua limitada influência prática no mundo desenvolvido. A julgar pelos dados macroeconômicos, na grande maioria dos países desenvolvidos, o máximo que se alcançou foi provocar uma desaceleração no ritmo de crescimento da participação do Estado na economia. Dos "neoliberais", pelo menos dos mais extremados, talvez se possa dizer o que dizia Napoleão dos ideológos em geral: "só aceitam teorias inaplicáveis e encontram-se a mil léguas da verdade prática do governo" (Bonaparte, 1996:54).

Como já foi mencionado, o aumento da participação do Estado nas economias desenvolvidas nas últimas décadas representou a continuação de uma tendência que remonta ao início do século. No campo econômico, sobretudo depois da Segunda Guerra Mundial, predominaram políticas macroeconômicas de tipo keynesiano. No campo social, construiu-se uma ampla rede de proteção social, o chamado Estado do Bem-estar.

O que vem acontecendo desde os anos 70 é uma tentativa, até agora não muito bem-sucedida, de reverter essa tendência. Busca-se fazer recuar a ação estabilizadora e reguladora do Estado, restaurar a era pré-keynesiana e reduzir o 
escopo das políticas sociais. O chamado neoliberalismo é uma revolta contra o século XX.

Em certo sentido, é até surpreendente a atenção que as idéias "neoliberais", mesmo nas suas versões mais extravagantes, vêm recebendo por tanto tempo. Parte da explicação está, sem dúvida, na crise prolongada do sistema soviético e na sua completa desintegração a partir do final dos anos 80 . O esgotamento do planejamento central contribuiu para reforçar o prestígio do seu antípoda ideológico. Como notou o grande economista keynesiano, James Tobin, perde-se freqüentemente de vista que quem ganhou a Guerra Fria não foi a economia pura de mercado, mas a economia mista, na qual os governos desempenham papel substancial e crucial (Tobin, 1996:181).

\section{O mito da empresa "transnacional"}

A outra face do mito do declínio do Estado é a idéia da ascensão de corporações "globais", supostamente livres de lealdades nacionais e apontadas como os principais agentes de uma avassaladora transformação da economia mundial. Também nesse ponto as teses mais extravagantes costumam prevalecer sobre a análise fria dos números e do comportamento das grandes empresas de atuação internacional.

Não há dúvida de que nas últimas décadas aumentou a proporção de firmas que operam em âmbito internacional. As corporações industriais e financeiras dos países desenvolvidos, e mesmo de alguns países em desenvolvimento, ampliaram as suas atividades no exterior e mantêm uma parte dos seus ativos fora do seu país de origem. Uma percentagem maior do valor adicionado é produzido por subsidiárias estrangeiras e cada empresa individual enfrenta maior número de competidores externos, tanto na sua base doméstica quanto em outros países (Wade, 1996:62-64).

Daí não segue, entretanto, que se possa falar em supremacia de empresas "transnacionais" ou "multinacionais", sem identificação nacional específica. Mesmo as grandes empresas, que tendem a ser mais internacionalizadas do que as pequenas e médias, permanecem marcadas por sua origem nacional. Corporações verdadeiramente transnacionais são raras, especialmente nas economias de maior porte, que contam com amplos mercados internos. E não se pode dizer que exista tendência perceptível de predomínio de empresas genuinamente globais, que não revelam preferência por um país particular.

A própria expressão empresa "transnacional" é enganosa, na medida em que insinua a ausência de base ou dependência nacional. Em geral, o conceito de empresa "transnacional" não é aplicável, vale dizer, não pode ser utilizado, como sugere o termo, para designar entidades que transcendem as nações e operam desvinculadas de suas origens nacionais (Gorender, 1996:13). São poucas as empresas que correspondem a esse modelo. A maioria das grandes corporações da Europa, dos Estados Unidos e do Japão concentra a sua atuação nos respectivos países. Funções centrais, como pesquisa e desenvolvimento, e as atividades geradoras de maior valor adicionado tendem a se realizar no país de origem das empresas. 
Robert Wade lembra que a grande maioria das firmas mantém a maior parte dos seus ativos, empregados e decisões estratégicas na sua base nacional. De um modo geral, a maior parte do capital acionário das empresas fica em mãos de pessoas físicas e jurídicas do país de origem. A Nestlé, por exemplo, uma das companhias mais internacionalizadas do mundo, que tem apenas $5 \%$ dos seus ativos e empregados na Suíça, limita os direitos de voto de estrangeiros a apenas 3\% do total. Em 1991 , apenas $2 \%$ dos membros dos conselhos de administração das grandes empresas dos EUA eram estrangeiros. Nas companhias japonesas, observou a revista The Economist, diretores estrangeiros são tão raros quanto lutadores britânicos de sumô (Wade, 1996:79).

Por essas e outras razões, as corporações devem ser caracterizadas, em geral, como firmas nacionais com operações internacionais (Wade, 1996:80). Mais apropriado é denominá-las corporações japonesas, alemãs, norte-americanas etc. Empresas de base nacional, ainda que orientadas para o mercado internacional.

Como observa Gorender, as corporações não se desligam dos Estados nacionais dos países onde têm origem. Constituem, ao contrário, uma questão de política internacional para esses Estados. O fato “concreto, palpável e, não raro, brutal” é que as empresas ditas transnacionais ou multinacionais precisam do seu Estado nacional para contarem com abrigo político e salvaguardas jurídicas nas suas atividades nos mercados domésticos e internacionais (Gorender, 1996:13-14).

Nesse particular, a postura das grandes empresas se caracteriza pela ambivalência. Por um lado, constituem a "base material" da ideologia da "globalização". Valem-se dela para criar um clima propício à remoção de barreiras contra a sua ação internacional e fazem questão de propagandear o seu caráter supostamente transnacional. Por outro lado, sempre que necessário, pressionam os governos dos seus países de origem para obter apoio econômico e político em suas operações no exterior.

$\mathrm{Na}$ disputa por grandes obras e contratos internacionais, essas empresas costumam recorrer à capacidade de intervenção dos seus Estados nacionais, a exemplo do que aconteceu recentemente no caso da acirrada concorrência entre a Raytheon dos Estados Unidos e a Thomson da França pelo comando do Sistema de Vigilância da Amazônia (Sivam). Enquanto países da periferia subdesenvolvida se deixam embalar pela retórica da "globalização" e das empresas "transnacionais", os governos dos países desenvolvidos continuam fazendo o que está a seu alcance para ajudar as empresas dos seus países (69).

69 Um exemplo característico do ponto de vista que prevalece sobre essas questões em certos círculos no Brasil pode ser encontrado em documento de autoria de um dos diretores do Banco Central. Nesse documento, as empresas "transnacionais" são apresentadas como portadoras de uma "nova identidade supranacional", com "amplas e profundas" implicações para o comércio exterior e para os fluxos de investimentos diretos. Segundo o autor, "a terminologia 'empresa transnacional' (...) expressa a consciência da nova natureza dessas empresas, originalmente multinacionais, mas que deixam de ter nacionalidade, ou perdem a noção de 'matriz', ao se racionalizarem globalmente" (Franco, 1996, p. 3-4). 
Há uma tendência bastante generalizada a exagerar o alcance do processo de internacionalização em curso no campo empresarial. Muitas análises se baseiam em dados inadequados ou parciais. Não basta, por exemplo, considerar o extraordinário crescimento dos fluxos de entradas e saídas de investimentos diretos registrados nas contas de capitais dos balanços de pagamentos. Para determinar o grau de internacionalização das empresas, é necessário avaliar o peso relativo das suas atividades domésticas e internacionais, isto é, comparar as vendas externas com as internas, verificar o percentual dos ativos mantidos no exterior, confrontar os lucros gerados domesticamente com os lucros gerados por subsidiárias e afiliadas no exterior etc. (Hirst \& Thompson, 1996:77-78).

Dados levantados por Hirst e Thompson indicam que a base doméstica continua sendo o centro das atividades das empresas internacionais dos principais países desenvolvidos. Algo como 70 a $75 \%$ do valor adicionado são produzidos no país de origem das corporações (Hirst \& Thompson, 1996:80-98). No caso do setor industrial norte-americano, dados levantados por L.Tyson (apresentados em trabalho que carrega o título sugestivo: "They are not us: why American ownership still matters") indicam que as matrizes nos EUA respondiam por $78 \%$ dos ativos totais, $70 \%$ das vendas totais e 70\% do emprego total das "multinacionais" dos EUA em 1988 (70).

No que diz respeito a atividades internacionais, as corporações dos EUA parecem ter passado por três fases no pós-guerra. Ao período de expansão no exterior que marcou as décadas de 50, 60 e 70, seguiu-se uma fase de diminuição das atividades internacionais, que durou até o final dos anos 80. Desde então, as empresas norte-americanas voltaram a ampliar as suas operações externas. A relação entre a produção bruta de suas filiais no exterior e o PIB dos EUA diminuiu de 8,2\% em 1977 para 6\% em 1989, aumentando de novo ligeiramente, para 6,2\% em 1991(71).

Um levantamento mais recente, publicado pela OCDE, confirma o predomínio das atividades domésticas das empresas do setor industrial dos países desenvolvidos, sobretudo nas economias de maior porte (tabela 12). Entre 1986 e 1995, observa-se um aumento no peso relativo das vendas de filiais no exterior, especialmente no caso do Japão. No entanto, a produção doméstica ainda prepondera por larga margem em todos os países incluídos na tabela, com exceção da Suécia. No setor industrial japonês, a produção interna corresponde a $90 \%$ da soma das vendas de filiais no exterior com a produção doméstica; nos EUA, essa proporção alcança $80 \%$; na Alemanha, $77 \%$ (tabela 12 ).

70 Dados reproduzidos em Hirst \& Thompson, 1996, p. 96-97.

71 United Nations Conference on Trade and Development, 1996, p.16. 
Tabela 12

Setor industrial em países desenvolvidos selecionados: produção doméstica e de filiais no exterior ${ }^{(1)}$

Em \%

\begin{tabular}{llll}
\hline Países & 1986 & 1993 & 1995 \\
\hline EUA & 83 & 80 & $(.)$. \\
Japãodo & 96 & 92 & 90 \\
Alemanba & 81 & 77 & $(.)$. \\
Itália & 84 & $76^{(3)}$ & $(.)$. \\
Suécia & 58 & $52^{(4)}$ & $(.)$. \\
\hline
\end{tabular}

(1) Participação da produção doméstica na soma das vendas de filiais no exterior coma produção doméstica; (2) Anos fiscais; (3) 1992; (4) 1990; (..) Dados não disponíveis.

Fonte: Organisation for Economic Co-operation and Development, OECD economic outlook, December 1996.

O quadro é semelhante para as atividades tecnológicas e de pesquisa e desenvolvimento. Hirst e Thompson estimam que apenas 10 a 30\% da atividade tecnológica das empresas "multinacionais" acontecem em subsidiárias estrangeiras (72). Wade destaca que "a esmagadora maioria da atividade tecnológica das maiores firmas do mundo é feita na base doméstica" (grifo do original), fato confirmado não só pela pequena proporção de despesas de pesquisa e desenvolvimento executadas no exterior, mas também por dados referentes a patentes. Nos anos $80,89 \%$ das patentes obtidas nos EUA por 600 das maiores empresas do mundo listavam como inventor um residente no país de origem da empresa (Wade, 1996:83-84).

Trabalho anterior, de Pari Patel e Keith Pavitt, já mostrara que as grandes empresas concentram as suas atividades de pesquisa e desenvolvimento nas suas bases nacionais. As firmas das principais economias do mundo - EUA, Japão e Alemanha - realizam menos de $15 \%$ da sua atividade tecnológica fora do país de origem. A produção de tecnologia, concluem os autores, constitui um caso importante de "nãoglobalização" (Patel \& Pavitt, 1991:1-21).

As corporações da Europa Ocidental realizam uma parcela maior das suas atividades de pesquisa e desenvolvimento fora do país de origem, o que reflete a unificação do mercado europeu e a existência de vários países tecnicamente adiantados, mas com mercados domésticos muito pequenos. Mesmo assim, é notável que

72 A estimativa baseia-se em dados referentes a companhias dos Estados Unidos, da Europa Ocidental e do Japão (Hirst \& Thompson, 1996, p. 97-98). 
uma companhia como a Philips, da Holanda, que mantém $85 \%$ dos seus ativos no exterior, ainda realize $40 \%$ das suas atividades de pesquisa e desenvolvimento na sua base doméstica (Wade, 1996:79-80).

O comércio exterior é outra área em que proliferam impressões exageradas quanto à extensão da influência das corporações "transnacionais" e a conseqüente perda de controle por parte dos Estados nacionais. Não parece ter base a suposição bastante comum de que o peso crescente dessas empresas estaria provocando modificação profunda do comércio internacional de bens e serviços. É verdade que empresas de grande porte, orientadas para o mercado internacional, respondem por parte significativa dos fluxos de comércio entre países. Também é verdade que boa parte desses fluxos constituem transações entre empresas do mesmo grupo, o que cria problemas importantes para o seu controle, inclusive do ponto de vista tributário.

Mas essas tendências não são novas (73) e os dados disponíveis não indicam crescimento generalizado do comércio intrafirma ou da participação das chamadas "transnacionais" nos fluxos totais de comércio. Poucos países fornecem estatísticas que permitem identificar a evolução das exportações e importações das empresas matrizes e de suas filiais no exterior. Mas existem dados para as duas maiores economias da OCDE - os Estados Unidos e o Japão -, para a Suécia e, de forma menos completa, para alguns outros países europeus.

Alguns desses dados estão reproduzidos na tabela 13. Observe-se que a participação das "multinacionais" dos EUA no comércio total de bens e serviços daquele país diminuiu entre 1982 e 1992, sobretudo do lado das exportações. A participação do comércio intrafirma cresceu pouco nesse período, tendo alcançado $23 \%$ das exportações e $18 \%$ das importações dos EUA em 1992. No Japão, houve crescimento tanto da participação das empresas "multinacionais" quanto do comércio intrafirma. Mas, do lado das importações, os percentuais japoneses são bem mais modestos. Para os países incluídos na tabela 13 , a participação do comércio intrafirma variava de $21 \%$ a $26 \%$ das exportações e de $7 \%$ a $18 \%$ das importações no início dos anos 90 .

\section{A dimensão financeira do processo de internacionalização}

A dimensão financeira é considerada por muitos autores como o aspecto decisivo do processo de internacionalização das décadas recentes. Robert Wade, por exemplo, observa que "a multinacionalização mais dramática ocorreu no plano financeiro" (Wade, 1996:64). Michel Rogalski refere-se às finanças como o "núcleo duro da mundialização" (Rogalski, 1997:9).

73 Bairoch e Kozul-Wright sustentam que, já no século XIX, boa parte do comércio internacional consistia de transações intrafirma. "É um mito", afirmam, "que a produção internacional seja um traço peculiar ao período atual de globalização" (Bairoch \& KozulWright, 1996, p. 9-10). 
Tabela 13

Participação de companhias "multinacionais" no comércio internacional de bens e serviços de alguns países desenvolvidos

$(\mathrm{Em} \%)$

\begin{tabular}{|c|c|c|c|c|}
\hline & \multicolumn{2}{|c|}{ Exportações } & \multicolumn{2}{|c|}{ Importações } \\
\hline & 1982 & 1992 & 1982 & 1992 \\
\hline \multicolumn{5}{|c|}{$\begin{array}{l}\text { Participação do comércio de companhias } \\
\text { "multinacionais" no comércio total }{ }^{(1)}\end{array}$} \\
\hline$E U A$ & 71 & 58 & 43 & 41 \\
\hline Japão & $76^{(3)}$ & 78 & $19^{(3)}$ & 23 \\
\hline França & $(.)$. & $44^{(4)}$ & $(.)$. & $22^{(4)}$ \\
\hline Suécia ${ }^{(5)}$ & 61 & 52 & $(.)$. & $(.)$. \\
\hline \multicolumn{5}{|c|}{$\begin{array}{l}\text { Participação do comércio intrafirma } \\
\text { no comércio total }{ }^{(2)}\end{array}$} \\
\hline$E U A$ & 22 & 23 & 16 & 18 \\
\hline Japão & $22^{(3)}$ & 26 & $4^{(3)}$ & 8 \\
\hline França & $(.)$. & $2 \mathrm{l}^{(4)}$ & $(.)$. & $7^{(4)}$ \\
\hline Suécia ${ }^{(5)}$ & 24 & 26 & $(.)$. & $(.)$. \\
\hline
\end{tabular}

(1) Participação das exportações ou importações das matrizes no total das exportações ou importações do país.

(2) Participação do comércio entre matrizes e filiais no exterior no total das exportações ou importações do país.

(3) 1983.

(4) 1993, apenas bens manufaturados.

(5) 1978 e 1990, apenas bens manufaturados.

(..) Dados não disponíveis.

Fonte: Organisation for Economic Co-operation and Development, OECD economic outlook, December 1996.

De fato, é nesse terreno que as transações internacionais vêm apresentando expansão mais acentuada. Também é aqui que fica mais evidente como o avanço tecnológico pode superar as barreiras naturais de tempo e espaço que separam os mercados nacionais (74). A remoção de controles sobre os movimentos internacionais de capital e a desregulamentação dos mercados financeiros domésticos, combinadas com o rápido progresso tecnológico em computação e comunicações e com a

74 International Monetary Fund, 1997b, p. 46. 
diversificação e sofisticação crescentes dos instrumentos financeiros, produziram ampliação extraordinária dos mercados, especialmente dos fluxos internacionais (75).

Até os anos 60, os países desenvolvidos mantiveram controles relativamente rigorosos sobre os movimentos internacionais de capital. No início da década de 70 , teve início um processo gradual de liberalização, que se estendeu por mais de 20 anos. Como o desmantelamento dos controles internacionais ocorreu em um período de desregulamentação dos mercados domésticos e de rápida inovação financeira e tecnológica, o resultado foi um dramático crescimento dos fluxos brutos de capital, especialmente desde os anos 80 (76).

Para as principais economias desenvolvidas, as transações internacionais brutas em títulos e ações, por exemplo, que equivaliam a menos de 10\% do PIB em 1980, passaram a representar quase sempre bem mais do que 100\% em 1995 (77). De acordo com levantamento trienal realizado pelo BIS, o giro diário médio nos mercados cambiais também vem aumentando a taxas elevadas, passando de um total estimado em US\$ 188 bilhões em 1986, para US\$ 590 bilhões em 1989, US\$ 820 bilhões em 1992 e nada menos que US\$ 1.190 bilhões em 1995 (78). Para se ter uma idéia do que isso significa, basta assinalar que, em 1995, as reservas totais nos bancos centrais dos países desenvolvidos, alcançavam U\$ 764 bilhões (79), menos de dois terços do giro diário nos mercados de câmbio. Outra área de crescimento rápido tem sido o mercado de derivativos. Entre fins de 1986 e fins de 1995, o valor de contratos envolvendo derivativos financeiros selecionados (futuros e opções de juros, futuros e opções de moeda, e futuros e opções de índices de mercados de ações) aumentou de US\$ 618 bilhões para US\$ 9.185 bilhões. O número anual de contratos com esses tipos de derivativos financeiros, negociados em mercados organizados, passou de 315 milhões em 1986 para 1.210 milhões em 1995 $(80)$.

Deve-se ressaltar, entretanto, que mesmo no campo financeiro a internacionalização é bem mais limitada do que sugerem esses números ou o uso freqüente de expressões como "globalização financeira" ou "mundialização do capital financeiro". Como nota documento recente do FMI, dedicado à questão da

75 The Economist, 1995, p. 3-4.

76 International Monetary Fund, 1997b, p. 60.

77 Id., Ibid.

78 Id., p. 64. O BIS observa, contudo, que a maior parte da taxa anual média de crescimento de $13,2 \%$, registrada entre 1992 e 1995, deve ser atribuída à depreciação do dólar dos EUA, moeda presente em mais de $80 \%$ das transações. Ajustada para excluir os efeitos dessa depreciação, a taxa média de crescimento diminui para $6,2 \%$ ao ano nesse período (International Monetary Fund, 1996b, p. 31, 120).

79 International Monetary Fund, 1997a, p. S6, S37. O dado inclui reservas de ouro contabilizadas a DES 35 a onça.

80 International Monetary Fund, 1996b, p. 68-69. 
"globalização", "o grau de integração dos mercados de capital é muito mais limitado do que parecem sugerir os fluxos brutos [de capital]" (81). Os movimentos líquidos de capital não apresentam o mesmo crescimento explosivo, observa o documento, e são bastante modestos quando comparados ao PIB ou aos níveis registrados durante o auge do padrão-ouro, antes de 1914. Na década de 90, os países desenvolvidos vêm apresentando desequilíbrios médios em conta corrente da ordem de apenas $2 \%$ do PIB (82).

De uma forma geral, as aplicações financeiras domésticas ainda são preponderantes por larga margem. Martin Feldstein observa que, embora a eliminação de controles de capital, especialmente nos países desenvolvidos, tenha ampliado as possibilidades de movimentação do capital entre países, a maior parte dos proprietários e administradores de fundos financeiros continua preferindo concentrar as suas aplicações nos mercados nacionais. "A maior parte da poupança fica nos países de origem", diz ele, "e muito do capital que se move internacionalmente está buscando ganhos temporários e se desloca rapidamente quando as condições mudam”. Em conseqüência, um país não pode contar com fluxos sustentados de capital externo para financiar o investimento doméstico, mesmo quando as oportunidades locais de investimento são atraentes (Feldstein, 1995:72-73).

O ponto de vista de Feldstein é confirmado por uma análise do comportamento dos investidores institucionais de países desenvolvidos, apresentada em outro documento do Fundo Monetário Internacional (83). Recorde-se que nos países desenvolvidos, e crescentemente nos países em desenvolvimento, os mercados de títulos têm sido cada vez mais dominados por um número relativamente pequeno de grandes investidores institucionais, notadamente fundos de pensão e companhias de seguro. Os ativos totais dos 300 maiores investidores institucionais dos EUA aumentaram de 30\% do PIB daquele país em 1975 para mais de $110 \%$ do PIB em 1993. Os fundos de pensão, as companhias de seguro e os fundos mútuos em cinco dos principais países desenvolvidos (EUA, Japão, Alemanha, Reino Unido e Canadá) administravam US\$ 13 trilhões em ativos em 1993, um valor significativamente maior do que o estoque de US\$ 9 bilhões da dívida governamental dos países do G-7 (84).

Dados o volume e o rápido crescimento dos fundos sob administração institucional, é importante verificar qual o grau de diversificação internacional desses investidores. Mais uma vez, os dados disponíveis não dão sustentação à tese de que estaria havendo um forte e generalizado processo de internacionalização, que pudesse justificar o uso de termos com "globalização financeira". As estatísticas apresentadas no documento do FMI mostram que, embora tenha ocorrido alguma diver-

81 International Monetary Fund, 1997b, p. 61.

82 Id., Ibid.. Ver, também, seção 2 deste trabalho.

83 International Monetary Fund, 1995, p. 165-174.

84 Id., p. 165-166. 
sificação internacional em determinados setores, o comportamento dos investidores institucionais, particularmente dos fundos de pensão e das companhias de seguro, continua marcado por um forte viés em favor dos mercados nacionais. O FMI atribui esse viés a uma combinação de fatores:

- ao caráter ainda relativamente recente dos processo de diversificação internacional dos portfólios de investidores institucionais;

- à marcada preferência de investidores individuais por ativos domésticos, em função de custos de transação, risco cambial, incertezas sobre retornos esperados e pouca familiaridade com mercados e leis tributárias no exterior;

- às restrições governamentais a aplicações no exterior;

- à aversão ao risco por parte dos administradores de fundos de pensão e outros investimentos (85).

Os fundos de pensão dos EUA, por exemplo, que administravam um total de US\$ 3,6 trilhões de ativos em 1993 (86), tinham apenas 5,7\% desse total aplicados no exterior. Os da Alemanha, 4,5\%. Os do Japão, 9\%. Só os fundos de pensão do Reino Unido, com 19,7\% dos seus ativos aplicados em papéis estrangeiros, é que revelam uma abertura mais significativa ao exterior (tabela 14).

As companhias de seguro de vida, que são depois dos fundos de pensão os investidores institucionais de maior peso, também apresentam forte propensão a aplicar no seu país de origem e, a julgar pelos dados reproduzidos na tabela 14, são quase sempre ainda mais introvertidas do que os fundos de pensão. As seguradoras dos EUA, por exemplo, mantinham apenas 3,7\% dos seu portfólio aplicados em outros países em 1992. As da Alemanha, 1\% em 1991. As do Japão, 9\% em 1993. O grau de abertura a aplicações externas só é mais significativo no caso dos fundos mútuos, particularmente na Alemanha e no Reino Unido. Mas, mesmo nesses países, as aplicações domésticas ainda são dominantes nos portfólios dos fundos mútuos (tabela 14).

A propensão dos investidores institucionais a aplicar nos chamados mercados emergentes é ainda menor. Embora tenha havido um aumento dessas aplicações nos anos recentes, o percentual dos portfólios institucionais investido nesses mercados é muito reduzido. Estimava-se que, em 1995, os investidores institucionais mantinham, em média, apenas cerca de $1 \%$ dos seus ativos em países em desenvolvimento (87).

85 Id., p. 168-169. Feldstein oferece explicação semelhante para o viés nacional dos investidores institucionais: "The reluctance of portfolio managers to invest more in foreign securities may reflect (...) a concern about low-probability events, such as repayment default or currency non-convertibility. Portfolio managers and fiduciary committees may also see their task as 'acting prudently' rather than maximising a risk-adjusted return" (Feldstein, 1995, p. 73).

86 International Monetary Fund, 1995, p. 166.

87 Id., p. 172. 
Tabela 14

Participação de títulos estrangeiros na carteira de investidores institucionais de países desenvolvidos selecionados

(Em \% dos ativos totais)

\begin{tabular}{|c|c|c|c|c|c|c|}
\hline & 1980 & 1988 & 1990 & 1991 & 1992 & 1993 \\
\hline \multicolumn{7}{|l|}{ Fundos de Pensão } \\
\hline Alemanba & (..) & 3,8 & 4,5 & 4,5 & 4,3 & 4,5 \\
\hline Bélgica $^{(1)}$ & 1,7 & $3,3^{(5)}$ & 3,3 & (..) & $(.)$. & (..) \\
\hline Canadá & 4,1 & 5,3 & 5,8 & 8,5 & 10,2 & 10,3 \\
\hline EUA & 0,7 & 2,7 & 4,2 & 4,1 & 4,6 & 5,7 \\
\hline Holanda: Privados & $10,6^{(4)}$ & $13,8^{(5)}$ & 21,1 & 23,5 & (..) & $(.)$. \\
\hline Públicos & $1,7^{(4)}$ & $2,8^{(5)}$ & 5,2 & 5,7 & $(.)$. & (..) \\
\hline Japão & 0,5 & 6,3 & 7,2 & 8,4 & 8,4 & 9,0 \\
\hline Reino Unido & 10,1 & 16,5 & 18,0 & 20,8 & 22,0 & 19,7 \\
\hline \multicolumn{7}{|c|}{ Companhias de Seguro de Vida } \\
\hline Alemanba & 0,6 & 0,6 & 1,0 & 1,0 & (..) & (..) \\
\hline Canadá & 3,3 & 1,9 & 1,6 & 1,9 & 2,3 & 1,8 \\
\hline EUA & 4,1 & 3,6 & 3,6 & 3,6 & 3,7 & (..) \\
\hline Holanda (2) & $5,2^{(4)}$ & $10,3^{(5)}$ & 9,3 & 10,3 & (..) & (..) \\
\hline Itália ${ }^{(2)}$ & 11,7 & $10,1^{(5)}$ & 1,6 & 9,7 & (..) & $(.)$. \\
\hline Japão & 2,7 & 14,2 & 13,5 & 12,5 & 11,4 & 9,0 \\
\hline Reino Unido & 5,5 & 9,5 & 10,8 & 12,4 & 12,7 & 11,6 \\
\hline Suécia ${ }^{(2)}$ & $(.)$. & $1,5^{(6)}$ & 10,4 & 12,5 & $(.)$. & $(.)$. \\
\hline \multicolumn{7}{|l|}{ Fundos Mútuos } \\
\hline Alemanba & $(.)$. & $(.)$. & 56,3 & 53,5 & 47,6 & 45,2 \\
\hline Canadá & 19,9 & 19,5 & 17,5 & 16,2 & 16,7 & 17,1 \\
\hline$E U A$ & $(.)$. & $(.)$. & (..) & 6,6 & (..) & 10,1 \\
\hline $\operatorname{Jap} \tilde{a} 0^{(3)}$ & $(.)$. & 9,1 & 7,9 & 13,0 & 9,9 & (..) \\
\hline Reino Unido & $(.)$. & $(.)$. & 37,1 & 39,2 & 37,9 & 36,0 \\
\hline
\end{tabular}

(1) Inclui companhias de seguro.

(2) Companhias de seguro.

(3) Consórcios de investimentos.

(4) 1983.

(5) 1985

(6) 1987.

(..) Dados não disponíveis.

Fontes: International Monetary Fund, International capital markets: developments, prospects and policy issues, August 1995; e Barry Eichengreen, International monetary arrangements for the 21st century. Washington, D.C., The Brookings Institution, 1994. 
É verdade que a tabela 14 também mostra que, no caso dos fundos de pensão, vem ocorrendo um aumento gradual da participação das aplicações no exterior desde 1980, pelo menos. Os fundos de pensão dos EUA, por exemplo, mantinham apenas $0,7 \%$ do seu ativo no exterior em 1980 . Os do Japão, $0,5 \%$.

Por outro lado, no caso das companhias de seguro de vida a tendência não é tão clara. As dos EUA e do Canadá, por exemplo, vêm diminuindo o peso relativo das suas aplicações no exterior desde 1980. O mesmo vem ocorrendo nos anos 90 no caso das companhias de seguro do Japão e, em menor medida, do Reino Unido (tabela 14).

No caso dos fundos mútuos, só se observa aumento da participação de aplicações no exterior nos EUA, de 6,6\% dos ativos totais em 1991 para 10,1\% em 1993. Já no Canadá, país para o qual há mais dados, nota-se uma tendência de queda da importância relativa das aplicações em papéis estrangeiros, de 19,9\% em 1980 para 17,5\% em 1990 e 17,1\% em 1993. Uma diminuição do grau de internacionalização também se observa nas aplicações dos fundos mútuos da Alemanha, do Japão e do Reino Unido (tabela 14).

A preponderância dos mercados nacionais também aparece de forma esmagadora nos dados referentes aos mercados de títulos e ações. Em 1995, o estoque de títulos (bônus, notas, commercial paper e títulos do Tesouro) em circulação nos mercados domésticos dos países do G-7 era 13 vezes maior do que o estoque de títulos emitidos por esses países nos mercados internacionais: US\$ 21,5 trilhões contra US\$ 1,6 trilhão (88) (tabela 15). Nos mercados acionários, também predominam as transações internas. Em 1994, as emissões domésticas de ações em cinco dos principais países desenvolvidos (Alemanha, Canadá, EUA, França e Reino Unido) alcançaram US\$ 167 bilhões, o equivalente a 13 vezes o valor emitido por companhias desses países nos mercados internacionais (tabela 16).

Em suma, quando se considera a introversão dos investidores institucionais dos países desenvolvidos e o peso dos mercados financeiros domésticos em comparação com os internacionais, fica claro que é prematuro admitir a existência de um mercado "global" de capitais. É o que conclui, também, o já citado documento do FMI sobre a questão da "globalização": "os mercados financeiros tornaram-se crescentemente integrados, mas estão longe de formar um único mercado global" (89).

88 Nos mercados domésticos, predominam os títulos emitidos pelo setor público, que responderam por $63,7 \%$ do estoque de títulos domésticos em fins de 1995 (International Monetary Fund, 1996b, p.59). Esse documento do FMI observa que "although the domestic debt markets are much larger than the international market, they have grown more slowly in recent years, reflecting fiscal consolidation efforts in industrial countries, which has slowed the rate of public issues ( $I d$., p. 58).

89 International Monetary Fund, 1997b, p. 65. 
Tabela 15

Mercados domésticos e internacionais de títulos nos países do Grupo dos 7

(Em U\$ bilhões)

\begin{tabular}{lrrr}
\hline & 1993 & 1994 & 1995 \\
\hline Mercados Domésticos de Títulos ${ }^{(1)}$ & & & \\
& & & \\
Alemanba & $1.378,0$ & $1.668,4$ & $1.906,4$ \\
Canadá & 469,6 & 463,6 & 503,3 \\
EUA & $9.340,2$ & $9.963,1$ & $10.726,0$ \\
França & 975,3 & $1.120,9$ & $1.275,7$ \\
Itália & $1.186,7$ & $1.398,9$ & $1.532,3$ \\
Japãa & $3.976,7$ & $4.750,0$ & $4.958,6$ \\
Reino Unido & 440,3 & 524,6 & 599,3 \\
Totaldo G-7 & $17.766,8$ & $19.889,5$ & $21.501,6$ \\
\hline & & & \\
Mercados Internacionais de Títulos ${ }^{(1)}$ & & & \\
& & & \\
Alemanha & 120,1 & 189,4 & 271,6 \\
Canadá & 146,9 & 165,5 & 177,9 \\
EUA & 176,9 & 209,3 & 272,8 \\
França & 153,1 & 186,1 & 207,7 \\
Itália & 70,2 & 85,2 & 92,8 \\
Japão & 340,1 & 360,6 & 367,7 \\
Reino Unido & 186,7 & 211,9 & 226,4 \\
Totaldo G-7 & $1.194,0$ & $1.408,0$ & $1.616,9$ \\
\hline
\end{tabular}

(1) Estoques em fim de período.

Fonte: International Monetary Fund, International capital markets: developments, prospects and policy issues, September 1996. 
Tabela 16

Emissões domésticas e internacionais de ações

para países desenvolvidos selecionados

(Em U\$ bilhões)

\begin{tabular}{lrrrr}
\hline & 1991 & 1992 & 1993 & 1994 \\
\hline Emissões Domésticas de Ações & & & & \\
& & & & \\
Alemanha & 8,0 & 11,0 & 11,8 & 18,0 \\
Canadá(1) & 11,6 & 12,0 & 17,3 & 13,0 \\
EUA & 70,6 & 84,5 & 116,2 & 66,3 \\
França & 42,6 & 46,6 & 42,4 & 48,2 \\
Reino Unido & 18,8 & 10,4 & 24,4 & 21,5 \\
Total & 151,6 & 164,5 & 212,1 & 167,0 \\
& & & & \\
Emissões Internacionais de Ações & & & & \\
& & & & \\
Alemanba & 0,7 & 0,2 & 0,2 & 2,7 \\
Canadá & 0,3 & 0,2 & 0,5 & 0,6 \\
EUA & 5,0 & 6,9 & 9,9 & 4,6 \\
França & 1,7 & 1,7 & 3,7 & 3,8 \\
Reino Unido & 6,4 & 3,3 & 4,4 & 1,0 \\
Total & 14,1 & 12,3 & 18,7 & 12,7 \\
\hline
\end{tabular}

(1) Inclui emissões internacionais.

Fonte: International Monetary Fund, International capital markets: developments, prospects and policy issues, September 1996. 
Diante do predomínio dos fluxos e estoques financeiros domésticos, e dado o regime de flutuação cambial administrada entre as principais moedas, não surpreende que estudo recente publicado pela OCDE tenha concluído que é relativamente baixo o grau de interdependência ou sincronização entre as taxas de juro de longo prazo das três principais economias desenvolvidas: os EUA, o Japão e a Alemanha. A influência de fatores externos pode ter aumentado, observa a OCDE, em função da maior diversificação internacional dos portfólios dos investidores em bônus. Não obstante, as taxas de juro de longo prazo continuam sendo determinadas primordialmente pelas condições econômicas domésticas. "Entre as três maiores economias", conclui o estudo, "as taxas de câmbio absorvem, em larga medida, as pressões resultantes de divergências entre as taxas de juro de um país e as dos seus parceiros; em conseqüência, as taxas de juro de longo prazo, bem como as de curto, em uma das três maiores economias podem variar, e freqüentemente variam, de forma relativamente independente dos desenvolvimentos nas duas outras economias" (90).

À luz de todos esses dados, pode parecer díficil entender a freqüência com que se faz referência ao poder dos mercados financeiros 'globalizados' e sua suposta capacidade de estabelecer vetos inamovíveis à condução das políticas econômicas nacionais. Em parte, isso se explica pelo fato de que o grau de internacionalização financeira hoje existente é sensivelmente maior do que o observado durante o sistema de Bretton Woods, nos anos 50 e 60. A interdependência das políticas macroeconômicas, embora provavelmente menor do que nos tempos do padrão-ouro, é certamente maior do que a que havia na época dos mercados financeiros mais segmentados e regulados, característicos das duas décadas que se seguiram à Segunda Guerra Mundial.

Nas décadas de 50 e 60, um regime de câmbio fixo ou bandas cambiais estreitas era compatível com algum grau de autonomia nacional na condução da política monetária, sobretudo no curto prazo. Países submetidos a choques assimétricos ou a ciclos econômicos não-sincronizados podiam, dentro de certos limites, praticar políticas monetárias divergentes, de acordo com suas prioridades nacionais, e ainda assim assegurar estabilidade das suas taxas de câmbio por algum tempo. Episódios de ataques especulativos contra moedas frágeis eram bastante comuns, mas os bancos centrais mostravam-se capazes de resistir por mais tempo à desvalorização cambial.

90 Organisation for Economic Co-operation and Development, 1996b, p. 34. Ver, também, International Monetary Fund, 1997b, p. 64. Um exemplo recente do baixo grau de sincronização entre as taxas de juro de longo prazo dos países desenvolvidos ocorreu no início de 1996, quando se verificou, de um lado, significativo aumento dos juros no Canadá, no do Reino Unido e nos dos EUA e, de outro, queda na Europa continental e estabilidade no Japão. Para uma análise do movimento divergente das taxas de juro de longo prazo nos principais países desenvolvidos no início de 1996, ver International Monetary Fund, 1996b, p. 16, 17. O FMI atribui essas divergências na variação das taxas de longo prazo ao fato de que as economias do Canadá, do Reino Unido e dos EUA encontravam-se em estágio diferente do ciclo econômico, com taxas de crescimento relativamente rápidas em comparação com as observadas na Europa continental e no Japão (Id., p. 17). 
O quadro agora é diferente. O crescimento das operações financeiras internacionais coloca limitações maiores à condução das políticas nacionais, particularmente no campo monetário-cambial. Os fluxos líquidos de capital podem ser menores do que nas décadas anteriores à Primeira Guerra Mundial, mas o volume bruto de transações financeiras, assim como a velocidade de deslocamento internacional dos fundos, são atualmente muito maiores (91).

Contudo, no debate brasileiro, nem sempre se destacam as implicações mais relevantes dessas mudanças no quadro financeiro internacional. Uma delas é justamente a dificuldade cada vez maior que têm os bancos centrais, mesmo os de maior peso, de sustentar o tipo de regime cambial que o Brasil resolveu adotar no passado recente. A ampliação dos fluxos internacionais de capital vem tornando cada vez mais difícil a defesa de regimes que se caracterizam por ancoragem cambial flexível, isto é, aqueles que estabelecem sistemas ajustáveis de câmbio fixo, prefixações, bandas cambiais estreitas etc.

Barry Eichengreen discute, desse ângulo, as perspectivas para os arranjos monetários e cambiais no século XXI. Eichengreen argumenta de forma persuasiva que, por causa do volume crescente de ativos líquidos ou voláteis e da maior mobilidade internacional do capital, a tendência é no sentido de uma polarização dos regimes cambiais factíveis, com crescente inviabilidade de regimes intermediários que envolvem a fixação de metas cambiais explícitas. Para ele, os países serão cada vez mais obrigados a optar entre dois sistemas básicos: a flutuação cambial administrada, que já é o regime cambial dos principais países desenvolvidos desde o início dos anos 70; e a unificação monetária ou regimes que se aproximem disso, como o currency board (Eichengreen, 1994). Nesse último caso, se inclui, como se sabe, o modelo adotado na Argentina desde 1991, que acarreta forte perda de autonomia nos campos monetário e cambial e só é aplicado, mesmo assim raramente, em economias muito pequenas ou que passaram por crises monetárias profundas (Batista Jr., 1993).

O mesmo ponto de vista é defendido por Max Corden, para quem o tamanho dos fluxos internacionais de capital, relativamente aos fundos à disposição dos bancos centrais, dificulta enormemente a defesa dos diferentes tipos de sistemas ajustáveis de câmbio fixo. A não ser em países que possam e desejem impor controles cambiais efetivos, sistemas cambiais desse tipo não são mais factíveis. A escolha, escreve ele, é entre a flutuação administrada e um "regime sólido" na forma de uma união monetária ou de um currency board (92). Os regimes intermediários, que esta-

91 The Economist, 1995, p. 9. Ver, também, International Monetary Fund, 1997b, p. 116.

92 Corden, 1994, p. 292-306. Evidentemente, os países que optam por um "regime sólido" estão abdicando do uso da taxa cambial como instrumento de ajustamento do balanço de pagamentos. Essa opção implica transferir o controle sobre a política monetária a um país hegemônico (no caso do currency board), adotar a moeda emitida por outro país (caso do Panamá) ou estabelecer uma união monetária com um banco central comum (caso da união monetária européia). Segundo Corden, excluídos os poucos países que escolherem um currency board e aqueles que eventualmente participarem da união monetária européia, a flutuação administrada parece estar em vias de se tornar a norma geral (Id., p. 304-305). 
belecem metas ou âncoras cambiais ajustáveis, como, por exemplo, o regime cambial que desmoronou na Europa em 1992-93, ou o sistema mexicano, que veio abaixo em dezembro de 1994, ou o que vigora hoje no Brasil, estão se tornando cada vez mais vulneráveis num mundo marcado por uma tendência à integração dos mercados financeiros e por crescente mobilidade internacional de capitais. Em certas circunstâncias, a defesa desse tipo de regime cambial pode revelar-se extraordinariamente custosa em termos de diminuição das reservas internacionais do banco central. Ou exigir taxas de juro internas proibitivamente elevadas.

Em 1997, a fragilidade desse tipo de regime foi novamente comprovada pelo colapso das moedas de diversos países do leste da Ásia. A maioria dos bancos centrais desses países vinha procurando estabilizar as taxas nominais de câmbio, mantendo o preço do dólar dos EUA em moeda nacional dentro de uma certa faixa de variação. A partir de julho de 1997, ataques especulativos poderosos, alimentados pela enorme massa de recursos voláteis em circulação nos mercados internacionais, resultaram em pressões irresistíveis contra as "âncoras" cambiais desses países, que foram sucumbindo sucessivamente, com alto custo em termos de desestabilização do quadro macroeconômico no leste da Ásia e de repercussões financeiras e comerciais em outras regiões do mundo. Essa experiência constitui mais uma ilustração dos perigos associados ao modelo cambial em vigor no Brasil.

Em um contexto mundial de ampla mobilidade internacional de capitais, a preservação da autonomia nacional na condução das políticas monetárias e cambiais depende, em grande medida, da escolha do regime cambial. Como se sabe, a flutuação cambial é o regime que melhor permite conciliar a internacionalização financeira com a persistência de divergências entre a situação e as prioridades das diferentes economias nacionais. Não é por acaso que, com poucas exceções, tem havido marcada preferência por regimes de flutuação cambial administrada, com diferentes graus de intervenção dos bancos centrais nos mercados de câmbio (93). Essa tem sido a tendência não só nos países desenvolvidos, como também nos países em desenvolvimento (Eichengreen, 1996:136-192).

Como lembra o presidente do Bundesbank, Hans Tietmeyer, é comum que as políticas e prioridades dos Estados nacionais variem em direções ou tempos diferentes. Por esse motivo, há limites para o que pode ser alcançado pelos esforços de coordenação internacional. "Se isso vale para as políticas financeiras em geral", observa ele, "deve valer especialmente para quaisquer tentativas de 'formalizar' arranjos cambiais. (...) Sejamos realistas: no futuro previsível, acordos cambiais 'formalizados' entre as principais moedas do mundo não são um caminho viável para se seguir" (Tietmeyer, 1995:208-209).

93 De acordo com o FMI, "policy makers came to appreciate that with floating exchange rates, capital mobility was not incompatible with independent monetary policy conducted to stabilize domestic economic activity" (International Monetary Fund, 1997b, p. 116). 
No entanto, o predomínio do regime de flutuação cambial está longe de reduzir os bancos centrais à condição de atores coadjuvantes. Agindo isoladamente ou em combinação com outros bancos centrais, as autoridades monetárias nacionais, particularmente nas economias desenvolvidas, conservam considerável poder de intervenção e continuarão a exercer grande influência sobre a trajetória das taxas de câmbio, a despeito de tudo o que se afirma sobre o poder supostamente irresistível dos mercados financeiros "globalizados".

\section{Mitos da "globalização"}

As percepções sobre a evolução do contexto internacional sempre condicionam, em certa medida, o debate sobre as opções de um país. Uma avaliação objetiva, nãomitificada, do quadro mundial constitui uma das precondições para a definição apropriada das políticas nacionais.

Apesar de marcadas por vulgaridades e simplificações, as discussões sobre a "globalização" ou "mundialização" da economia adquiriram, nos últimos anos, uma importância estratégica. Da forma como vem sendo conduzido, esse debate tem tido efeitos predominantemente negativos. Por um lado, ajuda a mascarar a responsabilidade pelas opções e decisões dos governos, obstruindo a crítica das políticas públicas. Por outro, inibe a reflexão sobre as alternativas de que dispõem os países na definição de suas políticas econômicas, sociais e de inserção internacional, contribuindo para imobilizar as iniciativas nacionais.

Para países como o Brasil, que ainda carregam traços acentuados do seu passado colonial, um debate como esse é sempre problemático. A ideologia da "globalização", principalmente nas suas vertentes mais extremadas, constitui um reforço considerável e falsamente moderno para a arraigada subserviência de muitos setores das camadas dirigentes do país, sempre prontos a atuar como prepostos dos interesses internacionais dominantes e a colaborar para uma integração subordinada à economia internacional. Nesse contexto, a "globalização" funciona como álibi para algumas posições tradicionais das elites locais.

Um dos principais efeitos desse debate tem sido o de propagar a impressão de que a margem de manobra dos Estados nacionais, especialmente na periferia do sistema econômico internacional, sofreu dramático estreitamento nas décadas recentes. Segundo as versões mais extravagantes da ideologia da "globalização", os Estados nacionais estariam indefesos diante de processos "globais" incontroláveis ou irreversíveis e teriam ingressado em uma época de inevitável declínio.

Ao longo deste trabalho, procurou-se argumentar que essas avaliações recentes sobre as tendências da economia internacional estão carregadas de exageros e mitos. Carecem freqüentemente de perspectiva histórica. Apóiam-se, em geral, em preconceitos e impressões superficiais, e não em um exame cuidadoso dos dados macroeconômicos internacionais. O próprio vocabulário - "globalização", 
"mundialização", "neoliberalismo", empresas "transnacionais" ou "multinacionais"está contaminado de distorções e conotações ideológicas.

A título de síntese, apresentam-se a seguir algumas das principais teses difundidas pela ideologia da "globalização" e as razões pelas quais cabe considerá-las mitos.

\section{Mito $n^{\circ} 1$}

“A 'globalização' inagura nova etapa na história econômica mundial; constitui processo irreversível, que conduziu a uma integração sem precendentes das economias nacionais".

Muitos dos fenômenos apresentados para sugerir o advento de uma nova era constituem a reprodução, sob nova roupagem, de tendências antigas. "Globalização" é uma nova palavra para um processo que remonta, em última análise, à expansão da civilização européia desde o final do século XV. A internacionalização econômica dos últimos 20 ou 30 anos tem precedentes históricos, notadamente nas décadas anteriores à Primeira Guerra. Em diversos aspectos, o grau de integração internacional alcançado entre 1870 e 1914 é comparável, ou até superior, ao observado na economia "globalizada" do final do século XX. A ilusão de que estamos experimentando um processo inteiramente inédito de internacionalização se deve, em parte, ao fato de que a integração internacional recente é, de fato, significativa quando comparada ao baixo grau de abertura das economias logo após a Segunda Guerra. Perde-se de vista que, entre 1914 e 1945, as guerras, a Grande Depressão e o protecionismo destruíram o sistema internacional da belle époque, acontecimento que bem mereceria a reflexão dos que acreditam na irreversibilidade dos processos históricos (ver seção 2).

\section{Mito $n^{\circ} 2$}

"Nas últimas duas ou três décadas, a 'globalização' produziu um sistema econômico fortemente integrado, de caráter supranacional, que tende inexoravelmente a unificar o mercado mundial, a dissolver as fronteiras nacionais e a reduzir a relevância dos mercados domésticos".

O processo de internacionalização observado nas décadas recentes não tem o alcance e muito menos o caráter universal sugerido pelo uso indiscriminado do termo "globalização". Está muito longe de provocar o desaparecimento das fronteiras ou ameaçar a sobrevivência do Estado nacional. É verdade que o progresso técnico e as inovações em áreas como informática, telecomunicações e finanças, combinados com a liberalização de mercados e a remoção de restrições a operações internacionais, vêm contribuindo para a maior integração das economias nacionais. Não obstante, os mercados internos continuam a preponderar, por larga margem, na absorção da produção, na geração de empregos e no financiamento dos investimentos. Além disso, os mercados de trabalho permanecem altamente segmentados por polí- 
ticas restritivas de imigração e outros obstáculos à movimentação internacional de trabalhadores. Os dados sobre a distribuição geográfica dos fluxos de comércio internacional e dos movimentos de capital também não confirmam a propalada imagem de uma economia "global" ou de um mercado mundial unificado. O quadro é de forte concentração das atividades internacionais nos países desenvolvidos, que respondem por dois terços ou mais dos fluxos de comércio e de capital. A própria expressão "globalização" é enganosa e deve ser evitada. É preferível utilizar termos como "economia internacional" ou "internacionalização econômica", mais compatíveis com um quadro mundial caracterizado, fundamentalmente, pelo intercâmbio entre economias nacionais distintas (ver seções 3 e 4 ).

\section{Mito $n^{\circ} 3$}

"Em conseqüência da 'globalização' e do predomínio das políticas 'neoliberais', os Estado nacionais entraram em processo de inevitável declínio e estão sendo compelidos a reduzir a sua presença na economia".

O predomínio ideológico do chamado neoliberalismo - que apesar do prefixo constitui uma tentativa de restaurar o ideário econômico do século XIX -, não chegou a modificar de maneira significativa e duradoura a dimensão do Estado na grande maioria das economias desenvolvidas. Não chegou sequer a interromper a tendência de aumento do peso do governo, medido por indicadores agregados, como a relação entre a despesa e a receita públicas e o PIB. O exame dos dados macroeconômicos das economias desenvolvidas indica que há uma enorme distância entre o discurso "neoliberal" e a realidade dos países onde essa ideologia teve origem (ver seção 5).

\section{Mito $n^{\circ} 4$}

"A economia 'global' vem sendo crescentemente dominada por empresas 'transnacionais', livres de identificação e lealdades nacionais".

A grande maioria das empresas permanece marcada por sua origem nacional. Corporações verdadeiramente transnacionais são raras, especialmente nas economias de maior porte, que contam com amplos mercados internos. Não há dúvida de que nas últimas décadas as empresas dos países desenvolvidos, e mesmo de aluns países em desenvolvimento, ampliaram as suas atividades no exterior e passaram a desenvolver uma parte das suas atividades fora de seu país de origem. Mas isso não significa que as firmas perderam as suas referências e vínculos nacionais. A grande maioria delas mantêm o grosso dos seus ativos, vendas e empregos na sua base nacional. As atividades geradoras de maior valor adicionado e funções estratégicas, como pesquisa e desenvolvimento, tendem a se realizar no país de origem das empresas. Em geral, as corporações não devem ser caracterizadas como "transnacionais" ou "multinacionais", mas sim como firmas nacionais com operações internacionais (ver seção 6). 


\section{Mito $n^{\circ} 5$}

"A expansão das transações financeiras internacionais criou um mercado 'global' de capitais extraordinariamente poderoso, diante do qual a autonomia das políticas nacionais e dos bancos centrais, mesmo nos países de mais peso, tende a desaparecer".

O grau de internacionalização das finanças é mais limitado do que sugere o uso indiscriminado de expressões como "globalização financeira" ou "mundialização do capital financeiro". A despeito da acentuada expansão das operações financeiras internacionais, as aplicações domésticas ainda são largamente predominantes. $\mathrm{O}$ comportamento dos investidores institucionais dos países desenvolvidos, particularmente dos fundos de pensão e das companhias de seguro, revela um forte viés em favor dos mercados domésticos. A preponderância dos mercados nacionais também aparece de forma esmagadora nos dados referentes aos mercados de títulos e ações. Por esses e outros motivos, é prematuro admitir a existência de um mercado global de capitais. É verdade que o aumento do volume e da velocidade das transações financeiras internacionais cria situações novas. Dificulta, por exemplo, a sustentação de certos tipos de regime cambial, especialmente daqueles que se caracterizam por alguma forma de ancoragem flexível, a exemplo do regime adotado pelo Brasil nos anos recentes. Não é por acaso que tem havido nas décadas recentes uma tendência marcada para a flutuação cambial administrada, não só nos países desenvolvidos, como também nos países em desenvolvimento, pois esse é o tipo de regime cambial que permite conciliar o crescimento das operações financeiras internacionais com a preservação da autonomia dos bancos centrais na busca de objetivos domésticos. Longe de estarem reduzidos à condição de atores secundários, os bancos centrais continuam e continuarão a preservar a sua autonomia e a exercer forte influência sobre os mercados de câmbio, agindo isoladamente ou em intervenções coordenadas com outros bancos centrais (ver seção 7).

Em suma, é preciso tomar distância das noções falsas ou exageradas que correm o mundo à procura de consumidores incautos. "Globalização" é um mito que exagera o peso e o alcance das forças econômicas de âmbito internacional. Os Estados nacionais, sobretudo nos países mais bem-sucedidos, não estão indefesos diante de processos econômicos "globais" incontroláveis ou irresistíveis. Ao contrário do que sugere o fatalismo associado à ideologia da "globalização", o desempenho das economias e o raio de manobra dos governos continuam a depender crucialmente de escolhas nacionais.

O fascínio com a "globalização" é revelador do estado de prostração mental e desarmamento intelectual em que se encontram países como o Brasil. Para superá-lo, poderíamos começar por uma reavaliação do quadro mundial e do papel dos Estados nacionais, desenvolvendo, sem inibições, a nossa própria concepção dos rumos que devem tomar as relações internacionais da economia brasileira. 
O essencial é não esquecer o que dizia de Gaulle. Certa vez, o jovem xá do Irã pediu-lhe conselhos e de Gaulle respondeu: "Monseigneur, on vous suggérera bien des habiletés. Ne les acceptez jamais. Je n'ai qu'une suggestion à vous faire, mais elle compte: mettez toute votre énergie à rester indépendant" (94).

Referências bibliográficas

BAIROCH, Paul. Globalization myths and realities: one century of external trade and foreign investment. In: Robert Boyer \& Daniel Drache (eds.), States against markets: the limits of globalization.London, Routledge,1996.

BAIROCH, Paul \& KOZUL-WRIGHT, Richard. Globalization myths: some historical reflections on integration, industrialization and growth in the world economy. Discussion Paper, n. 13, United Nations Conference on Trade and Development, March 1996 [mimeo].

BARRO, Robert J. Getting it right: markets and choices in a free society. Cambridge, Massachusetts, The MIT Press, 1996.

BATISTA JR., Paulo Nogueira. A armadilha da dolarização. Estudos Econômicos, v. 23, n. 3, set./dez. 1993.

O plano real à luz da experiência mexicana e argentina. Estudos Avançados, v. 10, n. 28, set./dez. 1996.

BERGSTEN, C. Fred. Competitive liberalization and global free trade: a vision for the early 21st century. Working Paper Series - 15, Institute for International Economics, Asia Pacific Economic Cooperation, 1996 [mimeo].

BONAPARTE, Napoleão. Aforismos, máximas e pensamentos. Rio de Janeiro, Newton Compton Brasil, 1996.

COMISIÓN Económica para América Latina y el Caribe. Balance preliminar de la economía de América Latina y el Caribe. Santiago de Chile, Naciones Unidas, 1996.

CORDEN, W. Max. Economic policy, exchange rates and the international system. Oxford, Oxford University Press, 1994.

EICHENGREEN, Barry. International monetary arrangements for the 21st century. Washington, D.C., The Brookings Institution, 1994.

Globalizing capital: a history of the international monetary system. Princeton, Princeton University Press, 1996.

FELDSTEIN, Martin. Global capital flows: too little, not too much. The Economist, June 24th 1995.

94 Citado em Malraux, 1971, p. 44. ["Meu senhor, vão lhe sugerir as mais variadas sutilezas e manobras. Não as aceite jamais. Só tenho uma sugestão a lhe fazer, mas ela conta: coloque toda a sua energia em permanecer independente".] 
FERNANDES, Luis. Os mitos da globalização e os desafios do desenvolvimento. Principios, n. 34, nov./dez.1996.

FERRER, Aldo. Los ciclos económicos en la Argentina: del modelo primario exportador al sistema de hegemonía financiera. Buenos Aires, Academia Nacional de Ciencias Económicas, 1995.

FERRO, Marc. História das colonizações: das conquistas às independências, séculos XIII a XX. São Paulo, Editora Schwarcz, 1996.

FRANCO, Gustavo H. B. A inserção externa e o desenvolvimento. Jun.1996 [mimeo].

GERBIER, Bernard. La continentalisation, véritable objet de la mondialisation. La Pensée, 309, ján../fév./mars 1997.

GORENDER, Jacob. Globalização, revolução tecnológica e relações de trabalho. Série Assuntos Internacionais - 47, Instituto de Estudos Avançados, Universidade de São Paulo, set. 1996 [mimeo].

HIRST, Paul \& THOMPSON, Grahame. Globalization in question: the international economy and the possibilities of governance. Cambridge, U.K., Polity Press, 1996.

INTERNATIONAL Labour Office. World employment 1996/97: national policies in a global context. Geneva, 1996.

INTERNATIONAL Monetary Fund. International capital markets: developments, prospects and policy issues. Washington, D.C., August 1995.

- World economic outlook. Washington, D.C., May 1996a.

. International capital markets: developments, prospects and key policy issues. Washington, D.C., September 1996b.

Estadisticas financieras internacionales. Washington, D.C., Febrero 1997a.

World economic outlook: globalization, opportunities and challenges. Washington, D.C., May 1997b.

KEYNES, John Maynard. The economic consequences of the peace. 1. ed.: 1919; republicado in: The collected writings of John Maynard Keynes, v. II. Cambridge, Cambridge University Press for the Royal Economic Society, 1971.

KRUGMAN, Paul. The localization of the world economy. In: Paul Krugman, Pop internationalism Cambridge, Massachusetts, The MIT Press, 1996.

MALRAUX, André. Les chênes qu'on abat.... Mayenne, Gallimard, 1971.

MINISTÉRIO do Planejamento e Orçamento. Indicadores da economia mundial, n. 7 , Secretaria de Assuntos Internacionais - SEAIN, Brasília, D.F., dez.1996.

NAYYAR, Deepak. Globalisation: the past in our present. Presidential Address, SeventyEigth Annual Conference of the Indian Economic Association, Chandigarh, 28-30 December, 1995.

NIETZSCHE, Friedrich. Menschliches, Allzumenschliches, Erster Band. 1. ed.: 1878; republicado in: Friedrich Nietzsche - Werke I, Herausgegeben von Karl Schlechta, Ullstein, Frankfurt am Main, 1972. 
ORGANISATION for Economic Co-operation and Development. OECD economic outlook 57. Paris, June 1995.

OECD eoonomic outlook 59. Paris, June 1996a.

OECD economic outlook 60. Paris, Dec. 1996b.

OECD economic outlook 61. Paris, June 1997.

PATEL, Pari \& PAVITT, Keith. Large firms in the production of the world's technology: an important case of 'non-globalisation'. Journal of International Business Studies, $\mathrm{v}$. 22, n. 1, First Quarter 1991.

PESSOA, Fernando. Páginas de estética e de teoria e criticas literárias. Lisboa, Ática, 1994.

ROGALSKI, Michel. Mondialisation: présentation et remarques complémentaires. La Pensée, 309, jan./fév./mars 1997.

ROGER, Alain. Prefácio: atualidade de Schopenhauer. In: Arthur Schopenhauer, Sobre o fundamento da moral. 1. ed.: 1841; republicado pela Martins Fontes, São Paulo, 1995.

SACHS, Ignacy. "Les quiproquos du débat sur la mondialisation”. La Pensée, 309, jan./ fév./mars 1997.

SUMMERS, Lawrence H. Shared prosperity and the new international economic order. In: Peter B. Kenen (ed.), Managing the world economy: fifty years after Bretton Woods. Washington, D.C., Institute for International Economics, 1994.

TANZI, Vito \& SCHUKNECHT, Ludger. The growth of government and the reform of the State in industrial countries. IMF Working Paper, Fiscal Affairs Department, International Monetary Fund, December 1995 [mimeo].

TAYLOR, A. J. P. From the Boer War to the Cold War: essays on twentieth-century Europe. London, Penguin Books, 1996.

THE ECONOMIST Newspaper Limited. A survey of the world economy. October 7th 1995.

THE WORLD Bank. World development report 1997: the State in a changing world. Washington, D.C., 1997.

TIETMEYER, Hans. Establishing a vision for stabilization and reform. In: James M. Boughton \& K. Sarwar Lateef (eds.). Fifty years after Bretton Woods: the future of the IMF and the World Bank. Washington, D.C., International Monetary Fund and World Bank Group, 1995.

TOBIN, James. Nations States and the wealth of nations: challenges and opportunities in an ever more interdependent world. In: James Tobin, Full employment and growth: further keynesian essays on policy. Cheltenham, Edward Elgar, 1996.

UNITED Nations Conference on Trade and Development. World investment report 1994: transnational corporations, employment and the workplace.Geneva, 1994.

World investment report 1996: investment, trade and international policy.

Geneva, 1996. 
U.S. Bureau of the Census. Current population reports: the foreign-born population, 1996. Washington D.C., U.S. Department of Commerce, March 1997.

WADE, Robert. Globalization and its limits: reports of the death of the national economy are greatly exaggerated. In: Suzanne Berger \& Ronald Dore (eds.), National diversity and global capitalism. Ithaca, New York, Cornell University Press, 1996.

WORLD Trade Organization. Annual report, v. II. Geneva, 1996.

ZEVIN, Robert. Are world financial markets more open? If so, why and with what effects?. In: Tariq Banuri \& Juliet B.Schor (eds.), Financial openness and national autonomy: opportunities and constraints. Oxford, Clarendon Press, 1992.

Paulo Nogueira Batista Jr. é pesquisador-visitante do Instituto de Estudos Avançados da Universidade de São Paulo.

Trabalho concluído em setembro de 1997. Alessandra S. Henrique de Almeida e Tatiana Castelo Chaves auxiliaram no levantamento bibliográfico e na preparação das tabelas. 